UDC 711.433:004.9+004.451+911.3

Sergiy Vasylovych Kostrikov,

Doctor of Sciences (Geography), Professor, Department of Human Geography and Regional Studies,

V. N. Karazin Kharkiv National University, 4 Svobody Sq., Kharkiv, 61022, Ukraine;

EOS Data Analitics Ukraine, LLC, 31 Alchevskyh St., Kharkiv, 61002, Ukraine, e-mail: sergiy.kostrikov@eosda.com, https://orcid.org/0000-0002-4236-8474

\title{
URBAN REMOTE SENSING WITH LIDAR FOR THE SMART CITY CONCEPT IMPLEMENTATION
}

С. В. Костріков. ДИСТАНЦЙНЕ ЛАЗЕРНЕ ЗОНДУВАННЯ УРБАНІЗОВАНОГО СЕРЕДОВИЩА ДЛЯ ІМПЛЕМЕНТАЦЇ̈ КОНЦЕПЦЇ̈ «РОЗУМНОГО МІСТА». У статті розглядається методологічна послідовність впровадження Концепиії «Розумного Міста» (КРМ) - від удосконалення і подальшого розвитку ї̈ окремих теоретичних положень до визначення заходів щзодо ї̈ практичної імплементачії через ГІС-моделювання і просторовий аналіз міського (урбанізованого) середовища на підставі даних дистанщійного лазерного зондування.

На підставі значного літературного огляду розглядаються як запити і виклики щьоо досліджень урбанізованих територій, взагалі, так і щуодо КРМ, зокрема. Робляться уточнення і узагальнення окремих положень иієї концепиії. Урбогеосистемний підхід подається сталою методологією, яка може суттєво додати до успішної реалізаиії КРМ. 3 точки зору изього підходу наводиться авторська дефініція категорії «Розумне Місто».

Розроблена і подається методична послідовність робочого прочесу «дистаниійне зондування - лідар - ГІС» для формалізованого відтворення «розумного міського середовища». Розглядаються ГІС-інтерфейс та функиіональність оригінального програмного веб-застосування із обробки лідар-даних. Зокрема, подається домашня веб-сторінка з трьома головними функціональними інструментами: Виокремлення архітектури забудов та іншої інфраструктури міста; Визначення динамічних змін у міських забудовах; Генерачія топографічної поверхні міста. У якості тільки кількох із множини можливих прикладів розглядаються n'ять сиенаріїв (иse cases - англ.) застосування програмного забезпечення для впровадження КРМ. На завершення узагальнюються результати дослідження, робиться наголос на необхідності розробки ключового компоненту системи підтримки прийняття рішень - бази геоданих для «урбанізованого геоінформачійного простору».

Ключові слова: лідар, дистанщійне лазерне зондування, урбанізоване середовище, геопросторова площчина концепціі «Розумне Місто», інтерфейс і функиіональність веб-застосування ГІС, сценарії застосування програмного забезпечення, система підтримки прийняття рімень.

С. В. КострИКОб. ДИСТАНЦИОННОЕ ЛАЗЕРНОЕ ЗОНДИРОВАНИЕ УРБАНИЗИРОВАНННОЙ СРЕДЫ ДЛЯ РЕАЛИЗАЦИИ КОНЦЕПЦИИ «УМНОГО ГОРОДА». В статье рассматривается методологическая последовательность реализации Концеепии «Умного Города» (КУГ) - от усовершенствования и дальнейшего развития ее отдельных теоретических положений до определению по определения мер по ее практической имплементации посредством ГИСмоделирования и пространственного анализа городской (урбанизированной) среды на основании данных дистанционного лазерного зондирования.

На основании значительного литературного обзора рассматриваются как проблемные моменты и вызовы, касающиеся исследований урбанизированных территорий, вообще, так и относящиеся к КУГ, в частности. Делаются уточнения и обобщение отдельных положений этой концепиии. Урбогеосистемный подход предлагается в качестве устойчивой методологии, которая может существенно поспособствовать успешной реализачии КУГ. С точки зрения этого подхода дается авторская дефиниция категории «Умный Город».

Разработана и представлена методическая последовательность рабочего прочесса «дистанционное зондирование лидар - ГИС» для формализованного моделирования «умной городской среды». Рассматриваются ГИС-интерфейс и функииональность оригинального программного веб-приложения для обработки лидар-данных. В частности, представлена домашняя веб-странииа с тремя основными функииональными инструментами: Выделение архитектуры застроек и другой инфраструктуры города; Определение динамических изменений в городских застройках; Генераџия топографической поверхности города. В качестве только нескольких из множества возможных примеров рассматриваются пять сценариев (use cases - англ.) применения программного обеспечения для реализации КУГ. В завершение обобщаются результаты исследования, подчеркивается необходимость разработки ключевого компонента системы поддержки принятия решений базы геоданных для «урбанизированного геоинформаиионного пространства».

Ключевые слова: лидар, дистанционное лазерное зондирование, урбанизированная среда, геопространственный аспект концепциии «Умный Город», интерфейс и функциональность веб-приложения ГИС, сиенарии применения программного обеспечения, система поддержки принятия решений.

Introduction of the problem. Global urbanization remains one of the most challenging present and future problem in the world. Moreover, the humankind probably still has not realized the multiple dimensions of this phenomenon. The world urban population has increased dramatically from 751 million in nineteen fifty to 4.2 billion in two thousand eighteen, according to the document issued by UN DESA [1]. This report also emphasizes that, despite its relatively lower level of urbanization in Asia, there are located up to $55 \%$ of the urban population of the world. There are numerous intriguing facts about the cities over the globe in different publications that merit attention. Thus, the tenth part of the population lived in thirty metropolises several year ago yet, while six hundred of cities possessed the world population quarter then [2]

Thus, the continuing significant growth of urban population all over the world, but, first of all, in Africa, Asia, and Latin America, forces us to seek 
for new advances in the Urban Studies domain, what primarily means to involve new approaches and techniques in the Information Technology and Urban Remote Sensing. Since the majority of developing countries are situated in the Tropical and Subtropical geographical belts, the drastic effects of that local urbanization on the tropical environment and the global climate deserve the closest attention [3]. Thus, remote sensing data processing and modeling tools, that may assist in urban studies, can hardly be overvalued. The First Earth Observation Summit issued in 2003 a declaration to organize the ad hoc international Group on Earth Observation (ad hoc GEO). The GEO plan has established a framework paper announcing the Global Earth Observation System of Systems (GEOSS) and outlined nine areas of its social benefits [4]. Quite a few publications have appeared since then, which contribute to the GEO Strategic Plan, while one of the most significant texts among all of them, in our opinion, is a book on remote sensing on sustainability [5].

GEO started a working plan a "Global Urban Observation and Information" Initiative since 2016. The top-managers of this initiative arranged six main aims for the period up to 2025 [6]. The key features of the contemporary urban development have caused a number of challengers that require the innovative technological introductions in urban studies. These challengers and the innovations have been already summarized in one of our previous papers [7]:

- With prompt development and changes of urbanization process, the studies of urban systems are also becoming more and more complicated;

- The number of cities increased and the urban territories have been enlarged with a rapid speed, especially in developing countries;

- Fast growing regions with extensive urban constructions become more and more numerous;

- A necessity for accurate terrain models for urban planning or related sophisticated spatial data processing becomes quite understandable;

- A need for effective automated buildings survey to determine quantity and quality characteristics of architectural changes that took place over time is accepted as a mandatory component of urban monitoring;

- Precise environmental surveys over the key cities in the regions with extensive remote sensing data analysis should be regularly provided.

Despite the urban areas cover only $2 \%$ of the globe surface in the latest years, they possess more than half of the world population, and consume up to three quarters of the total produced energy, which, in its turn, generates more than $80 \%$ of greenhouse effect [8]. Thus, it is evident that a problem of optimal development for urban settlements has been a major problem for their residents, builders, and municipalities since past centuries. The definition of "urbanism" itself was introduced as long ago as at the end of the nineteenth century [9]. This definition was already considered then as a delineated category of transforming urban slums into the livable environment with the goals of delivering it into sustainable one. The source, we have just referred to, made an origin of quite a few publications, but the book "City: its growth, its decay, its future stands alone in this row [10]. Practically, just this book introduced the understanding of smart cities as distinct entities, also it employed somewhat another lexicon for description those geographical spaces intended to improve city livability and workability. That in contemporary terms means - to make a city to be more sustainable. Actually "Sustainable Cities" and "Digital Cities" were those intermediate benchmarks, through which "the Cities of the Future" category has been transformed into the Smart Cities fundamental idea [11]. The IBM Corporation was really the first institution, which began to develop the Smart City concept (the SCC) within the frameworks of its "Smarter Planet initiative" by the end of the first decade of this century, when the drastic economic crisis burst out [12]. The first Smart City advances have been summarized as an integration of the modern technologies, features of urban sustainability, and social implication [13].

The ultimate research goal of our paper is to represent an effective multifunctional approach, which would combine the author's urbogeosystem theory [7] with the Urban Remote Sensing (URS) technique for LiDAR (Light Detection and Ranging) data processing provided by the original web-based GIS-software [14]. Such combined attempt contributes both to the theoretical clarification of a city role as a driver for all environmental and urban systems, and to the applied implementation of the Smart City Concept.

The key elements of the Smart City concept within a geospatial perspective. Since exactly the geographic information of urban development such as maps of regional topography and vegetation, infrastructural network maps and census maps is highly necessary for the SCC implementation exactly because of this concept's definite geospatial perspective. Precisely this affiliation (a geospatial perspective $\Leftrightarrow$ the Smart City concept) implies at least three basic assumptions and up to five key elements.

Firstly, the innovative methods, in particular, the urban remote sensing for the relevant geodatabase content are mandatory to be involved.

Secondly, the original theoretical approach, e.g., the concept of urban geographical systems has to be chosen for an effective processing pipeline construction in a case of a robust and consistent im- 
plementation of the SCC. These both first, and second assumptions have been already highlighted in the introductory section of our paper.

Thirdly, those key elements of the SCC, that directly connected with its geospatial perspective, should be delineated, explained, and listed. This is being done in this section of the paper.

The huge number of publications in the SCC domain have appeared only for few recent years. It looks like to be some problem to choose the necessary core elements of this concept from a tremendous number of relevant definitions made. Due to existing thoughts, such key element as an innovation can be selected as a leading one in the general outline of this approach [15]. The key constituents of this extended review of the Smart Cities's working definitions include: "A city well-performing in a forward-looking way..." [16, P. 8]; "A city that monitors and integrates conditions of all of its critical infrastructures" [17]; "....connecting the physical infrastructure, the IT infrastructure, the social infrastructure, and the business infrastructure to leverage the collective intelligence of the city" [18]; "...combining ICT and Web 2.0 technology with other organizational, design and planning efforts to.... help to identify new, innovative solutions to city management complexity, in order to improve sustainability and livability" [19]; "The use of Smart Computing technologies to make the critical infrastructure components and services of a city....... more intelligent, interconnected, and efficient" [20].

Thus, the innovation as the Smart City concept's first key element is implied in one way or in another in all these five quotations mentioned above. We do accept exactly this idea, because an urban innovation can be implemented only in a geospatial perspective of the urban space, while this perspective is being considered in the next section of our paper. In this aspect we define a Smart City as a comprehensive procedure of innovations within the urban trinity: 1) urban residents, 2) local infrastructural network, both municipal, and commercial, 3) urban processes and phenomenon.

The Smart City concept's second key element may be selected as its scalability. The normal way of the SCC evolution is its moving from some particular projects to some international strategies, through which the city challenges are addressed upon different scales - national, regional, international [21]. These authors, we have just referred to, emphasize: "Thus, it has been observed that it is necessary develop a strategy within city framework to articulate projects in different dimensions in order to achieve a holistic and comprehensive vision". According to this, the global scale is the mandatory premise of City balance in various dimensions, which only can contribute to the SCC good perfor- mance. Without the global goals, the SCC sooner of all performs quite vague projects, which results are not able to be expanded to other scales. Many researches do agree with such conclusion [13, 22-24]. The global or national scales may provide negative impact on urban sustainability and, understandably, on the SCC implementation perspectives, because of the peculiarities of the pollical system in a certain country, as in contemporary Russia [25].

Thus, the cities corresponding to the SCC can be displayed as the instrumental combination across many urban scales [26]. These technological and information instruments are connected through multiple networks in a city, and some of these networks can provide continuous data concerning the movements of human and physical capitals. From these flows of initial data, the flow of derivative data is generated, which substantially contributes to the formation of the whole city content. Nonetheless, the cities become smart, only if they provide some intelligence functions. These functions mix, integrate, and combine initial data purposely, finding the ways of enhancing the efficiency, social equity, environmental security, and long-term sustainability of residents' life in smart cities. After all, it is quite understandable, that the Smart City's scalability is also related to its geospatial perspective.

Gathering, measuring, and mining of the spatial urban data can be accepted as the Smart City concept's third key element. Flows of people, materials, and energy within urban areas can be automatically sensed for the time being due to the modern information technologies, and the data relevant are generated. This has taken place mainly for three latest decades. These data enhanced by the remote sensing information were normally gathered and displayed with geoinformation tools, firstly with desktop ones, and later on with the processing and visual systems on the web, where various urban maps used for navigation, spatial distribution values, and predicting spatial estimation were the ultimate results [27-32].

While satellite remote sensing pixel images with urban information have been significantly employed for several recent decades, the LiDAR surveying technique gradually becomes the dominant one as both local, and regional scale sensing, what can be available with the variety of scanning hardware and point cloud data processing software appeared mainly in two recent decades [33]. An Airborne LIDAR system usually returns a 3D cloud of point measurements from mirrored features scanned by the laser beneath the air-flight route. This threedimensional cloud with irregular spacing reflects various discrete feature within some AOI (an area of interest). The laser-scanned features normally include buildings, other human infrastructure objects, 
different vegetation belts (canopy and understory), and "bare earth." To generate a Digital Elevation Model (a DEM), measurements from ground and nonground objects have to be calculated and classified. We can utilize the linear least squares interpolation technique iteratively to remove tree measurements and generate a DEM in urbanized areas.

The key premise of the involvement of the urban remote sensing in general, and the LiDAR surveying technique, in particular, as well as the employment of the geoinformation technology for the contemporary urban studies is conditioned by the fact that the digital sensors have become the main source of the initial information for the Smart City's concept implementation. Modern digital sensors and GIS-technologies for the urban traffic information processing can suggest robust topological model of optimized traffic trajectories, which contribute to the sustainable urban traffic evolution [34-37]. These systematic studies are normally implemented through those gathering, measuring, and mining of the spatial urban data. Moreover, these procedures lie within already mentioned the SCC geospatial perspective too, and put together that third key element of this concept.

The addressing environmental challengers is considered as the Smart City concept's fourth key element within its geospatial perspective, and the last but one in the list introduced in this paper section. Understandably typical challenges are urban pollution and a necessity to pacify the greenhouse effect. It is a well-known fact, large urban areas consume more, than $75 \%$ of energy generated in the world [38]. It is understandable that many studies focused on the urban environmental policy as long ago as few decades before the Smart City concept took its contemporary form. For example, the seminal book "Nature and the City" takes a look back at early nineties discussing the new policy discourse for looking at urban environmental problems within the frameworks of the ecological modernization concept [39]. This monograph highlights the case studies of environmental policy making in two big cities - Toronto and Los Angeles. The important performance of the actual environmental entities, river watersheds, in urban landscapes of both cities are emphasized, and this is only one from many examples of the geospatial perspective involvement. Addressing environmental challengers upon the SCC implementation should be provided in the most possible complex way by combining these (environmental) issues with other ones related to economic and social projects, governance, human issues and living standards [21]. Only this complex and combined outgoing derivative result can be accepted as the fundamental for the elaboration of the Smart City strategy for meeting present and future city problems in various urban dimensions. Alternatively, some authors introduce the category of "Larger Environmental Context", in which they include different dimensions, almost those ones, which compound various constituents of the derivative result mentioned above - economic, social, cultural, and even geopolitical issues [15, 40, 41].

The interlink between the smart meter information and the geo-sensor information, which is used to achieve knowledge and awareness with respect to human - urban environment interactions, is the fifth key element of the SCC in the geospatial perspective. It is the last one in our list, and the whole content of this SCC key element is reasoned by a complicated interlacement of physical and digital technologies with environmental and social phenomena in a city, while derivative information about this interlacement must be sensed, recorded and quantified [42-44]. With drastic increase of smart meter and digital sensors and completion of such entities, like the advanced metering infrastructure and the Internet of Things, a Smart City has to be equipped and covered with different networks of electronic devices. These networks must be sustainable enough with respect to the city social dynamics, and moreover - concerning probable unfavorable environmental events [45, 46].

Various sets and varieties of physical/digital sensors and digital/physical meters within a given urban area are able to contribute to functional configurations of urban decision support systems (UDSS) only in case, when these sensors and meters can delineate as effective picture of an urban life as it possible exactly in its spatiotemporal context [42, 47-49]. The spatiotemporal context of urban information is that only entity, which actually opens the geospatial perspective of the SCC. Just because of urban population high densities and concentrations in a typical city area, the latter consists of numerous interactions (human - urban environment; human urban infrastructure; urban infrastructure - urban environment) between urban citizens and their surroundings and produces extremely complicated view of the human geographical phenomenon of a given city. An UDSS mentioned above if planned to be involved in the SCC implementation should have an option to register the dynamics of those interaction within different city districts, on different dates, and at different times. Only upon these conditions a complete geospatial perspective can be seen on the base of the empirical urban information gathered from sensor networks.

Thus, we have outlined in this paper section following five key elements of the Smart City concept in the geospatial perspective: Innovations; Scalability; Data gathering, measuring, and mining; Addressing environmental challengers; Interlink 
between the smart meter information and the geosensor information.

In two following sections we, first of all, examine more in details one from three basic assumptions of the "geospatial perspective $\Leftrightarrow$ Smart City concept" affiliation - the urbogeosystem approach. Then we consider involvement of five key elements delineated in building the city geospatial information space.

The urbogeosystemic approach as a tool for simulating the "smart urban environment" - a core node of the Smart City hierarchy. The author of this paper has already published several texts in the concept of urban geographic systems for few recent years [7, 50-53]. As the key premise of the urbogeosystemic approach the theory of cities as systems of systems has been taken, which was introduced as long before as in late seventies of the former century [54]. Once we did outline the category of an urban geographic system as follows. An urbogeosystem (UGS) is ".... an urban system, which... ....not only allows providing all necessary prerequisites for GIS (a geographical information system) involvement in urban studies, but also secures detailed consideration of the most of linkages and relationships within a given area and reveals pure emergent properties...." [7, P. 110].

Although the urbogeosystematic approach has been listed above only as the second key assumption of the Smart City concept's implementation within a geospatial perspective, it can be understandably accepted as the central combining one, which builds a bridge between the urban remote sensing and outlined above five key elements of the SCC - two other key assumptions. In this way all three ones become linked together, while a real urbogeosystem, that functionates within a certain extent of the geographical space, can be presented by the urbogeosystemic ontological model (UOM). We understand the latter as some kind of a trinity-tripod, that strongly relies on support for and on interconnections among all three of its constituents ( $\underline{\text { urban citi- }}$ zens, municipal infrastructure, urbanistic processes and phenomena), what taken all together provide that sustainable operating of a given city, which can be evaluated as "smart operating" according to several existing criteria. Moreover, the UOM facilitates to delineate the core issue of the Smart City concept within its geospatial perspective - a place of the "smart urban environment" in the whole hierarchy of the series of environments related to a Smart City (Fig. 1).

The author of this paper has outlined the UOM hierarchy based on what was introduced before as "smart city models" in several literature sources [11, $15-17,26,55-58]$. Really all these models correspond to the "cities as systems of systems" theory, according to which a smart city is a system, that consists of a number of sub-systems. The practical implementation of the SCC can be exactly started from a creation of a simulating model for a certain selected city. This simulating model is based on the urban remote sensing data, in general [59], or on the LiDAR surveying results, in particular $[7,14,33$, 50]. After a city computer model is generated, desirably, according to 3D City GML standards, the structure of the conceptual UOM of an urban geographical system outlined on the figure below is reasonable to be accepted as the ultimate architectural design for this model, that simulates a Smart City. If the "smart urban environment" is a core node of this targeted construction of an urbogeosystem as illustrated, then numerous technological, environmental, and socioeconomic solutions made on the way to the SCC implementation, should be oriented to outlined hierarchy of this UOM (see Fig. 1) [51].

All dimensions in one way or in another involved in the initial presentation of the urbogeosystemic approach [50-53] can be delineated in the urbogeosystemic ontological model outlined above: 1) urban remote sensing data; 2) an applicable Human Geography model; 3) digital information processed into the GIS-primitives; 4) the definite geospatial aspects of all interrelated states of urban environment delineated by this ontological model of an urbogeosystem.

In their turn, all five key elements of the SCC within its geospatial perspective can be easily found within the UOM hierarchy too: innovations made in the municipal infrastructure will definitely impact urban processes and local residents; scalability becomes an almost mandatory issue due to the necessity to provide policy and management through various spatial scales and socioeconomic scopes; data mining makes it possible to view the information proceeding from all three pillars (people, processes, city infrastructure) in a whole picture; environmental challengers are dominant in few blocks of the UOM hierarchy; and interlink among various sources of urban digital information is the only one, which makes this hierarchy to be sustainable one. Summarizing two first sections of our paper, that directly examine the Smart City entity, related urban phenomena, and relevant solutions, it is necessary to complete one more only issue - to attempt to outline the Smart City category from the urbogeosystemic approach's point of view. As basic fundamentals for such outline can be selected those generalizing definitions, which from our point of view are the closest ones to our comprehensive frameworks $[15,56$, $60,61]$.

Thus, the Smart City from the point of view of the urgogeosystemic approach is a city, which operates as a system of sub-systems in robust, sustaina- 
ble, and intelligent way. It is a city that possesses a comprehensive commitment to digital technologies, information managerial practice, and public policy. Three supporting pillars for such city are people - its residents, managed urban processes, and infrastructural networks, while the core entity for a whole construction is the "smart urban environment" (see Fig. 1).

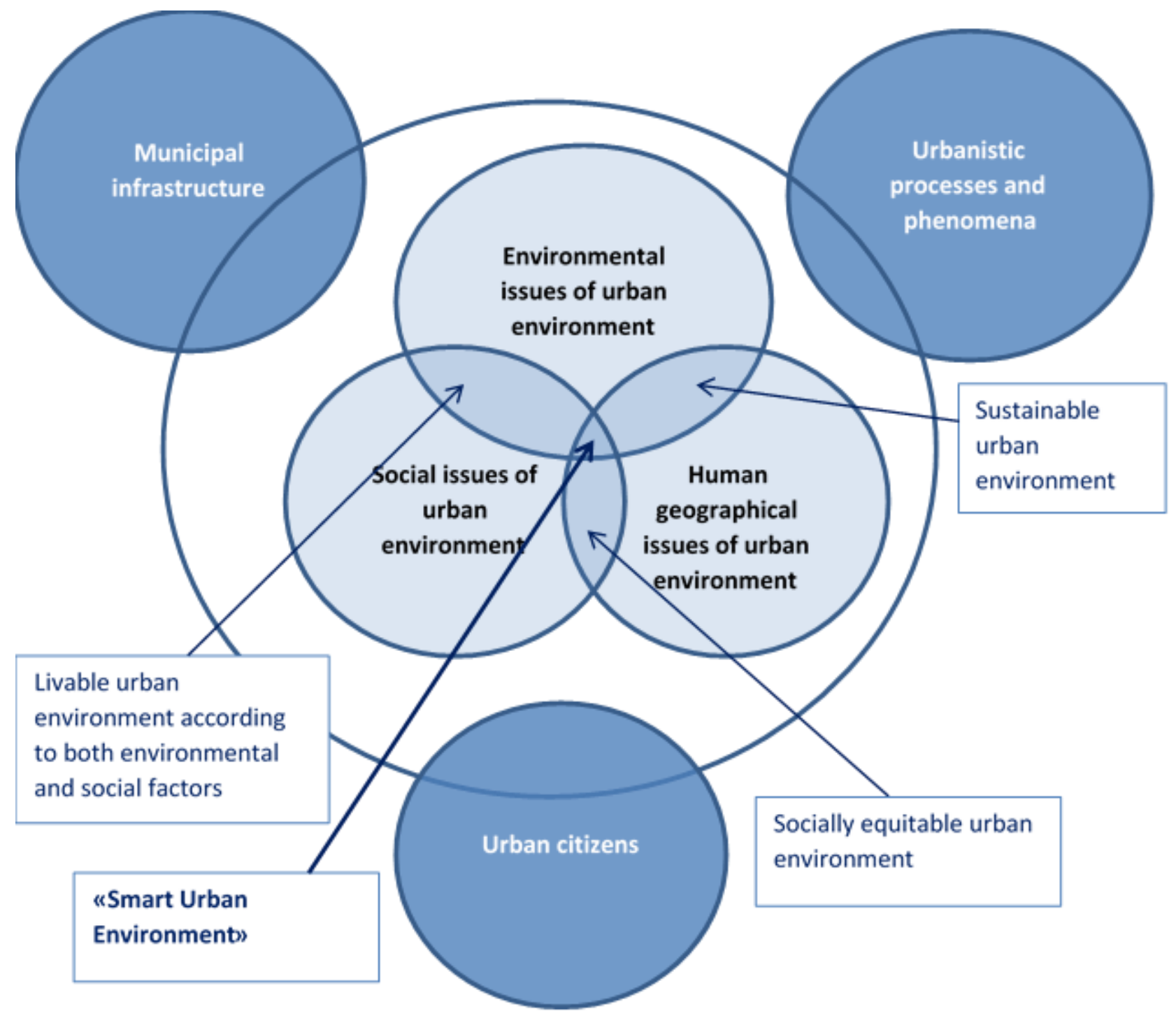

Fig. 1. An ontological model of the UGS with a place of the smart urban environment" in the whole hierarchy of the series of environments related to the Smart City [51, P. 110]

Processing results of LiDAR surveying technique. Both Airborne and Terrestrial LiDAR survey have been very demanded in urban environment because of its uniqueness in comparison with other URS results. We have already explained and proved, why $3 D$ city models obtained from a LiDAR survey through extraction, segmentation, reconstruction, and analysis can hardly be overvalued [7, 62].

Key publications that introduced and discussed similar ideas have been issued for ten-fourteen recent years only [33, 63-67]. The automated building and other man-made feature extraction from LiDAR point clouds together with the relevant topography generation is one of the most challenging research and development goals for city monitoring procedures as well as for support the urban environment by means of informatic software and digital networks. Airborne Laser Surveying (ALS) technique or LIDAR has become quite popular since late nineties, because it provides a fast data collection for a 3D Scene over a massive territory [68].

Contemporary research technique normally combines other data on extracting buildings or uses pre-defined building models, so that the latter would correspond to the roof structures. Surely there are quite a few alternative solutions in the literature to reconstruct the 3D buildings without any supplementary data and predefined roof styles [69]. Also, some attempts were published as long as 15 years ago, that related to use the captured data and convert them into CAD-type models, which would contain walls, roof planes and other building segment planes 
as well as bare ground which can be promptly visualized from any $3 \mathrm{D}$ viewpoint [70].

We have already mentioned above a key subject of LiDAR applications for urban studies $-3 D$ City Models. Besides this the LiDAR surveying technique has been broadly used in many other urban studies, thus becoming a fundamental for the Smart City concept implementation. In the key existing reviewers on LiDAR survey and its results processing for urban land cover classification, five basic domains have been toughly discussed: (1) urban architectural morphology and vegetation analysis, (2) urban flood risk assessment, (3) extracting power transmission lines and other infrastructure, e.g., bridges and roads, (4) modeling GPS/airport signal obstacles, and (5) estimation of solar radiation potential [33, 71].

All LiDAR platforms are either Airborne LiDAR (ALS) - Unmanned Aerial Vehicle (UAV LiDAR), or Terrestrial (Mobile) (MLS) ones. With drastically expanding demand for 3D city models and relevant DEMs, also taking into account increasing availability of ALS / MLS data, 3D building models of robust topology and correct geometry have become the most prominent features of urban environment modeled by LiDAR data processed [14, 33, 50, 62, 65-70, 72, 73]. Evidently, 3D city models as representations of a 3D geometry of urban environment can be obtained from quite various sources [74], but just LiDAR data accepted as the most preferable ones according to the series of understandable reasons. In general, all applied domains of LiDAR surveying techniques may be defined by three following advantages of its approach: 1) High accuracy of the geospatial data collected by LiDAR. Its Point Clouds may illustrate the location of real natural landscape / urban features in a minute details, while an infinitesimal peculiarity may make difference, and it can obscure the whole view of a 3D Scene; 2) Data through an AOI can be collected promptly, and in a costly effective way. Thus, it is possible to hold a quite accurate geospatial monitoring of large areas. This allows to identify urban change detection from multitemporal LiDAR data sets; 3) LiDAR surveying technique provides collection of raw data concerning all the features on the earth surface that belongs to three sets: inanimate nature, vegetation cover, and man-made constructions, buildings, first of all.

Summarizing 1)-3) items that directly relate to the Smart Cities solutions, we should emphasize that the key advantage of the LiDAR technique may lie in that perspective, which allows to build 3D city models within huge territories in an extremely short period of time. Just due to this fact the technology can hardly be overvalued for the urban planning industrial area. What is more, correct 3D city mod- els as well as highly accurate DEMs are required for many applications implemented within urban areas including Telecom-issues and wireless communication (the line of sight calculation, optimal allocation of transmitters), emergency response planning, air / noise pollution modelling, municipal infrastructure planning. It is remarkable that all this listed generally coincides with the Smart City necessities reported not only for Western Europe [42, 46], but also for Ukraine [75], as well as for Russia [76].

Our understanding of the LiDAR processing software position in the original illustration with the comprehensive operational URS / LiDAR / GIS workflow for the Smart City implementation is defined on Fig. 2. This flowchart directly proceeds from all introduced in our text above.

Urban Remote Sensing for data mining / city analytics and the EOS LiDAR Tool. ELiT (EOS LiDAR Tool) software is both a separate web-based (network) generator (an engine) - ELiT Server, and an integrated component of EOS Platform-as-aService software - ELiT Cloud, both developed with leading participation of this paper's author $[7,14$, $62,77]$. The allied one to these two products is our desktop ElitCore software, that possesses even broader functionality. All three mentioned products are the sophisticated solutions based on the complicated algorithms for urban environment modeling and analysis. Two products of this software family normally perform from the Web browser installed on the user's workstation. A series of ELiT end user's cases can be applicable with all five ELIT key functionalities: BE - Building Extraction, BEF-Building Extraction with Footprint; BERA - Building Extraction Rural Area, CD - Change Detection, DEM-G Digital Elevation Model Generation [Fig. 3]. Some of these use cases are presented in the next section of this paper.

First of all, we have to examine briefly straightforward advantages of using this LiDAR data processing software and to outline what peculiarities would demonstrate any applied Smart City project of real data, that we attempt to complete?

In previous attempts the delivery "urban settlements into smart cities" have been considered, realized, and planned through several levels $[26,28$, $78]$, and the scalability procedure mentioned in this text above could be applied then for interchange of the information obtained from various levels. By processing LiDAR data, the ELiT software provides huge volumes of information for different applications and reveals several attractive advantages due to applying to these urban levels, over traditional methods for mapping with other remote sensing data. ELiT functionalities result from that fact, according to which LiDAR data alter the whole concept of urban mapping and gaining popularity in domains 


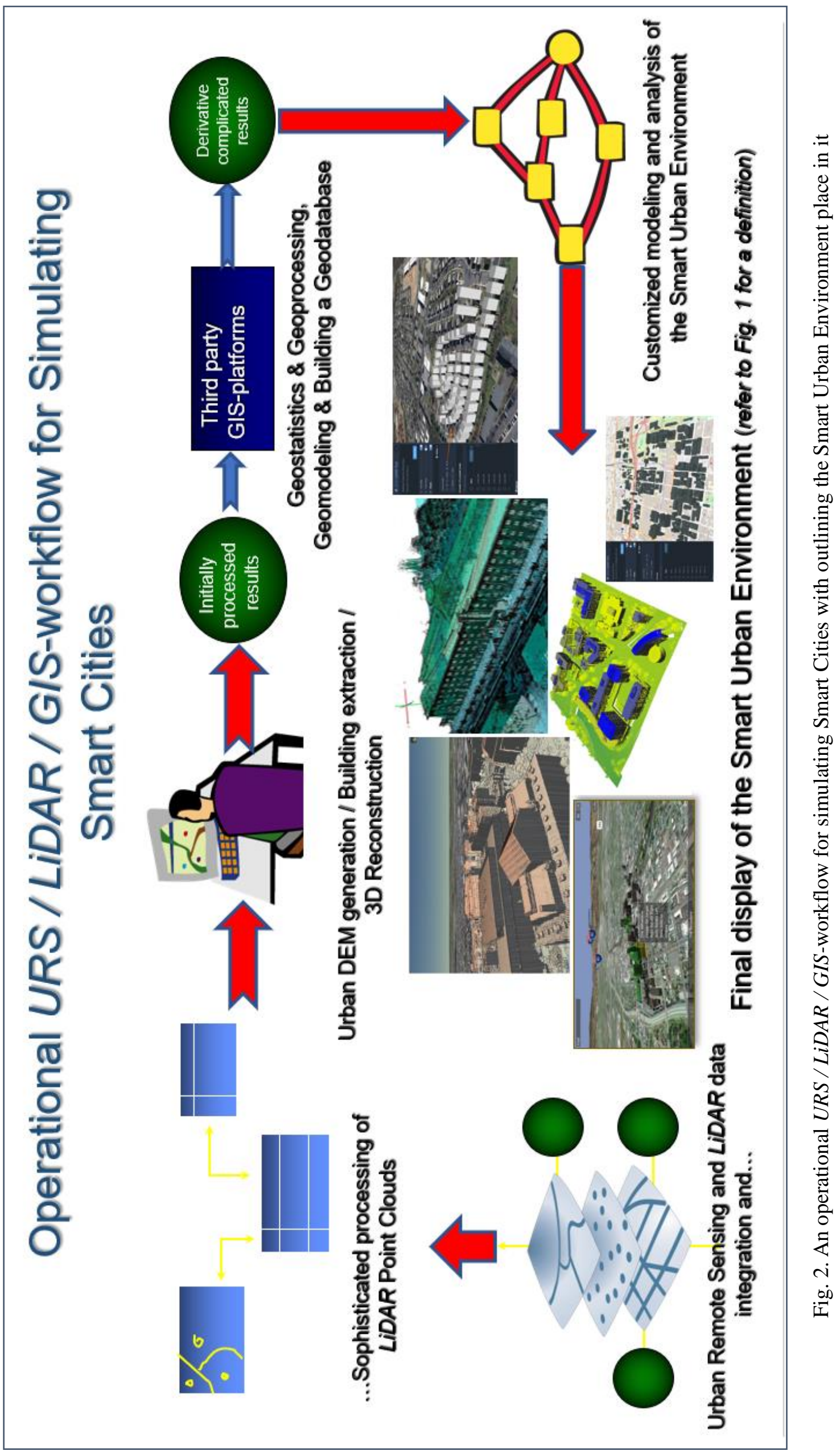


such as heavy urban networking and massive data integration, pollution monitoring and urban land classification. All these domains can take an advantage of combining LiDAR data and ELiT geoinformation functionality to provide analysis and manage, visualize, and disseminate results of sophisticated processing of LiDAR Point Clouds as it outlined on Fig. 2. After a block of $3 D$ Reconstruction a flowchart leads to the unit of Geomodeling \& Building a Geodatabase.

The ELiT multifunctional approach is that key premise, which connects up all these diverse components in the robust geoinformation workflow (refer to Fig. 2). The key output of this workflow, Final display of the Smart Urban Environment, is the applied results of a theoretical entity presentation outlined and explained earlier (refer to Fig. 1). In this way, processing results of LiDAR surveys ELiT software can relate the infrastructures of smart cities to their optimal planning and further functioning through the urban decision support systems mentioned in this text above in a case, when ELiT Server becomes a functional component of such UDSS. Five menus of relevant sub-pages suggest then all necessary calibrated instruments for municipal solutions within three basic classes of the functionalities necessary: Automated Feature Extraction, Urban Change Detection, Topographic Modeling \& Analysis (refer to Fig. 3).

Despite single known lame summarizing, where one could hardly see any connection between LiDAR and Smart City issues, although it attempts to provide some "direct bridge" from one to another [79], the majority of other "heavyweight" examples, if they are not directly related to the provision of LiDAR results for Smart Cities, but they suggest the definitely relevant solutions in subject areas of: 1) solid, impervious surface extraction in urban areas [80,81], what, as a rule, strongly indicates marginally urbanized landscapes; 2) quality assessment of urban environment [33, 82]; 3) monitoring of city alterations through change detection [83-86]; 4) urban feature extraction and $3 D$ reconstruction for city planning; there is a real "universe" of literature in this area, thus we do not make any relevant number of references in this \#4, but refer only to few key ones [33, 62-64, 70, 73, 87-89]; 5) geoscience applications for urban studies; processing results of LiDAR scanning equipment can provide uniquely accurate topographic $X, Y$, and $Z$ coordinates of the bare ground surface, including large topographic forms [90] what is highly demanded for urban housing development as well as damages from natural hazards (landslides, debris flow, earthquake damages), which can occur in city areas [91-93].

Feasible ELiT software use cases for the SCC implementation lie within each of 1)-5) issues and can be provided by all five options of this webapplication menu TOOLS: Building Extraction, Building Extraction with Footprint, Building Extraction Rural Area, Change Detection, DEM Generation (refer to Fig. 3). According to the mandatory limited volume of this paper we are able to examine only a couple of combined use cases related to $B E / B E F$ / $B E R A$ functionalities.

The range of Smart City applications dealing with these ELiT functionalities is quite long: urban and municipal planning, environmental planning and monitoring, insurance policy and procedures, optimization of sensor placement for technological networks, locational based services, housing development simulations, shadow estimation. In all these use cases a building model can be a primary object of interest. Although the ELiT approach does not prescribe any semantics to these models, it is possible such simplified models to interpret city dynamics and networks by examining spatiotemporal changes, and even estimating land use and services distribution in an urban area [94]. Besides these industrial areas we can outline the necessity of building model extraction from Point Cloud .LAS due to following reasons:

- to generate complex city mapping products;

- to provide various building renderings;

- to perform advanced three-dimensional modeling as the first step to creating complete and multifunctional digital city models.

Low cost per a surveyed city parcel, functionality of monitoring through a large urban /rural territory promptly and with high level of details are only first few primary advantages of the robust LiDAR pipeline, that necessarily includes the ELiT functionalities. Joining of the global mapping coverage (e.g., ESRI imagery, Open Street Maps) with the ELiT BE / BEF/ BERA / CD / DEM-G models expedites in easier understanding of the existing urban situation and needs much less resources for interpretation of derivative results, than traditional manual city maps, or even 2D digital cadaster units. Operational decision-making can be completed in a very prompt and cost-effective way within a given urban area with a number of multifunctional ELiT 3D city models.

For a few recent years most of the urban data, that can be used for understanding a smart city, have come from the GIS data collecting techniques that include 1) the satellite-enable GPS georeferencing provided for the URS procedures, 2) results of data collecting from technological networks with digital sensors, 3) results of data collecting from dense built-up areas that demonstrate a definite small-scale heterogeneity, 4) data from scanning surveying techniques that differ within a range of a whole city/ 


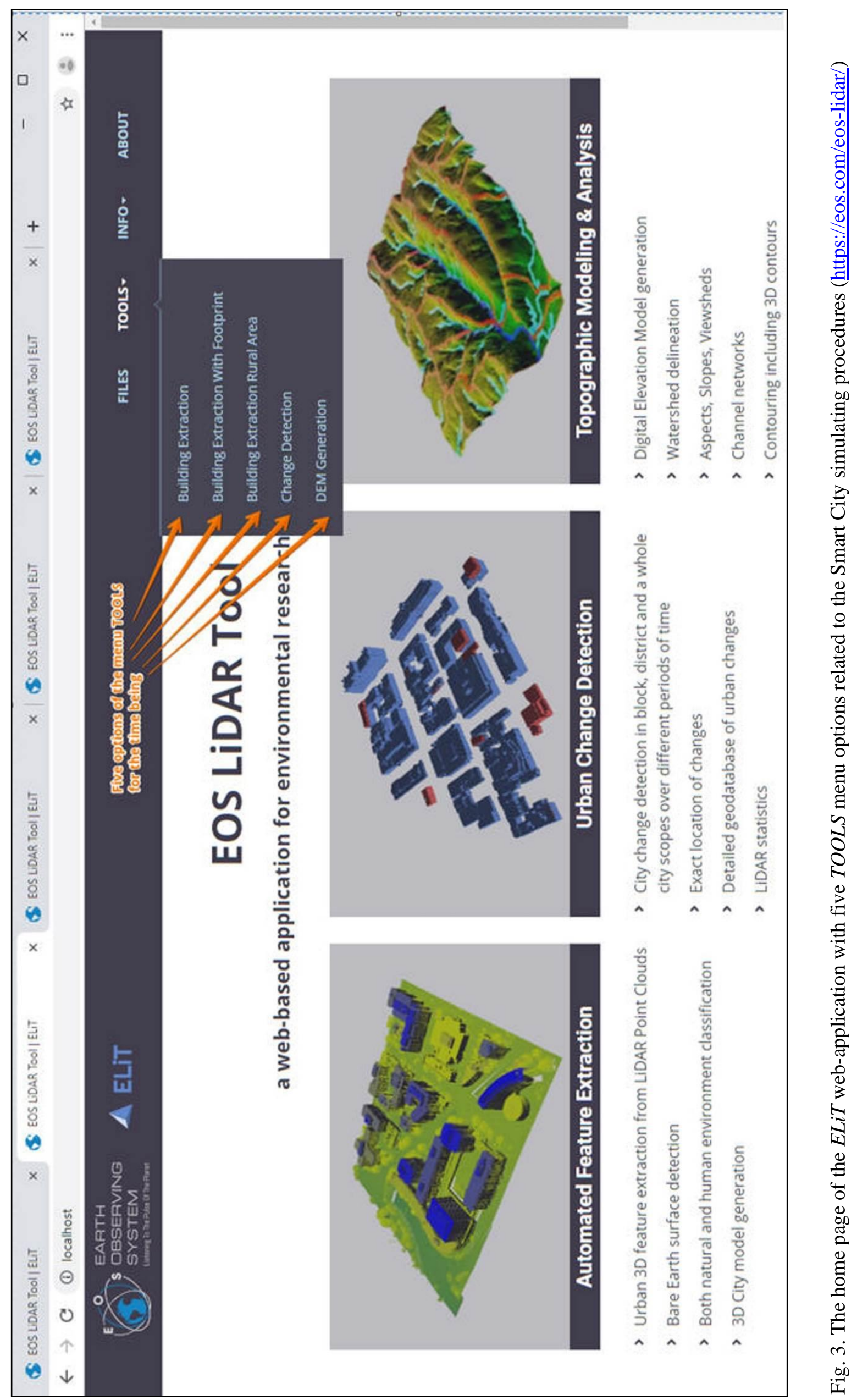


a city district / a block scopes, and even can focus on minute city parcels, 5) data acquisition from multiple sources of different nature including on-line sensors, 6) completion of 1)-5 issues integration in the newly geodatabases for Smart Cities, what would correspond to Building a Geodatabase block of an operational URS / LiDAR / GIS-workflow (refer to Fig. 2).

URS data mining / city analytics for the Smart Cities, which consists of six relevant to urban data issues delineated above, strongly corresponds to the geospatial perspective of the Smart City concept, in general, and to five key elements of the SCC in the geospatial perspective, in particular. On the base of the following references all six issues delineated for urban data mining can be easily put in compliance with three key subject areas examined in our paper: Data collection, integration, and further processing for the SCC implementation, including spatiotemporal data management and adding data value by integration of the massive data by ICT (Information and Telecommunication Technologies) [26, 60, 95]; Urban remote sensing, which generates, first of all, building information, which is used for several applications directly related to the paradigm of the Smart Cities, enhancing routing URS technique by computer vision and socioeconomic approaches [93, 95, 96]; LiDAR surveying technique for the "smart urban environment" simulation (refer to Fig. 1) [63$68,73,80-93,98,99]$. The whole framework of the URS data mining also implies the following three steps of each use case development that should take place for any ELiT functionality selected for the SCC implementation:

1. Selection of an appropriate functionality for a given project data requirement, taking into account the working environment, in which the given LiDAR dataset are being collected. 2. Definition of a complete and transparent approach to define uncertainty in urban modeling with respect to modeling error measurements such that the urban planning procedure bankability requirements are met. 3. Undertaking reliable and transparent comparison of the ELiT modeled results with the other information (a municipal cadaster, global maps, etc.) due to city buildings, infrastructures, other assets, and topographic surface.

The Urban Planning domain mainly is the disciplinary area of the strategic and long-term land use planning, which considers several aspects of both natural and human environments for municipalities and communities [100]. The key issue in here is that upon the SCC this subject area becomes much broader and, what is more, it triggers through URS data mining, ICT involvement and digital networks. The municipalities have to obtain an efficient geoinformation spaces is a mandatory pre-requisite for planned urban growth and functioning the system-wide effect in operations and functions of this urban area. The only possible solution that takes this effect into account is the join-up urban planning, which means reliable tracking of this effect even upon the massive data integration [26, P. 491].

The effective method for meeting the coming demands in Smart Cities urban planning and management sectors is to develop the georeferenced $d a$ ta of LiDAR survey web-based processing application and $a$ Web GIS-platform for the generation of 3D city models. The latter, in their turn, would significantly contribute to simulation of the completely new urban intelligence operations and functions by the modern ICT, that are provided for sustainable functioning of urban territories. Such combination (LiDAR survey + Web-application, e.g., ELiT + GIS-platform) can be considered as the only tool for modeling and displaying an entity, which we outline as the "Smart Urban Environment".

The ELiT software use cases for the Smart Cities. As it has been emphasized above, only use cases related to $B E / B E F$ / BERA functionalities can be briefly examined in this text. Georeferencing an urban territory and populating it with exactly allocated 3D city models make it much easier for municipal managers to understand a problem arisen under a way to a Smart City, and enables all city services for its prompt solution by geometric / topologic visualization and analysis of the ELIT 3D models. All use cases introduced below are strongly within an operational URS / LiDAR / GIS-workflow illustrated above (refer to Fig. 2).

ELiT use case (UC) sample 1 for common urban planning may be displayed like follows (Fig. 4). For a given housing area (Washington, D.C., open source data from https://aws.amazon.com/ru/blogs/ publicsector/lidar-data-for-washington-dc-is-

available-as-an-aws-public-dataset/) our software would assign point objects to one definite class from four nominated (i.e. ground, vegetation, buildings, other infrastructure). Efficient spatial classification as an input secures further applying of thematic feature layers delineation and allows to provide the prompt visual feature analysis "on a fly". Some alternative classes for four mentioned above may be Buildings, Vegetation, Artificial ground, Natural ground. Moreover, apart from buildings, there may be in derivative classifications the sets like follows: Trees, Grassland, Bare soil, Infrastructures. Thus, it is allowed to state that the ELiT representation of an urban area can meet "the overall challenge of integrating contextual information into geospatial analysis for smart cities..." [42, P. 17021], what means combining both technical, and research components in urban planning. As a final output within the frameworks of UC sample 1, a number of geometry 
definition format files (either .GLTF, or .KML formats) are produced, where each file represents one separate building extracted.

All this completes a combined $3 D$ picture of a certain urban area, which can be almost of any size according to city borders upon applying a scalability procedure.

Since commonly high-resolution LiDAR data

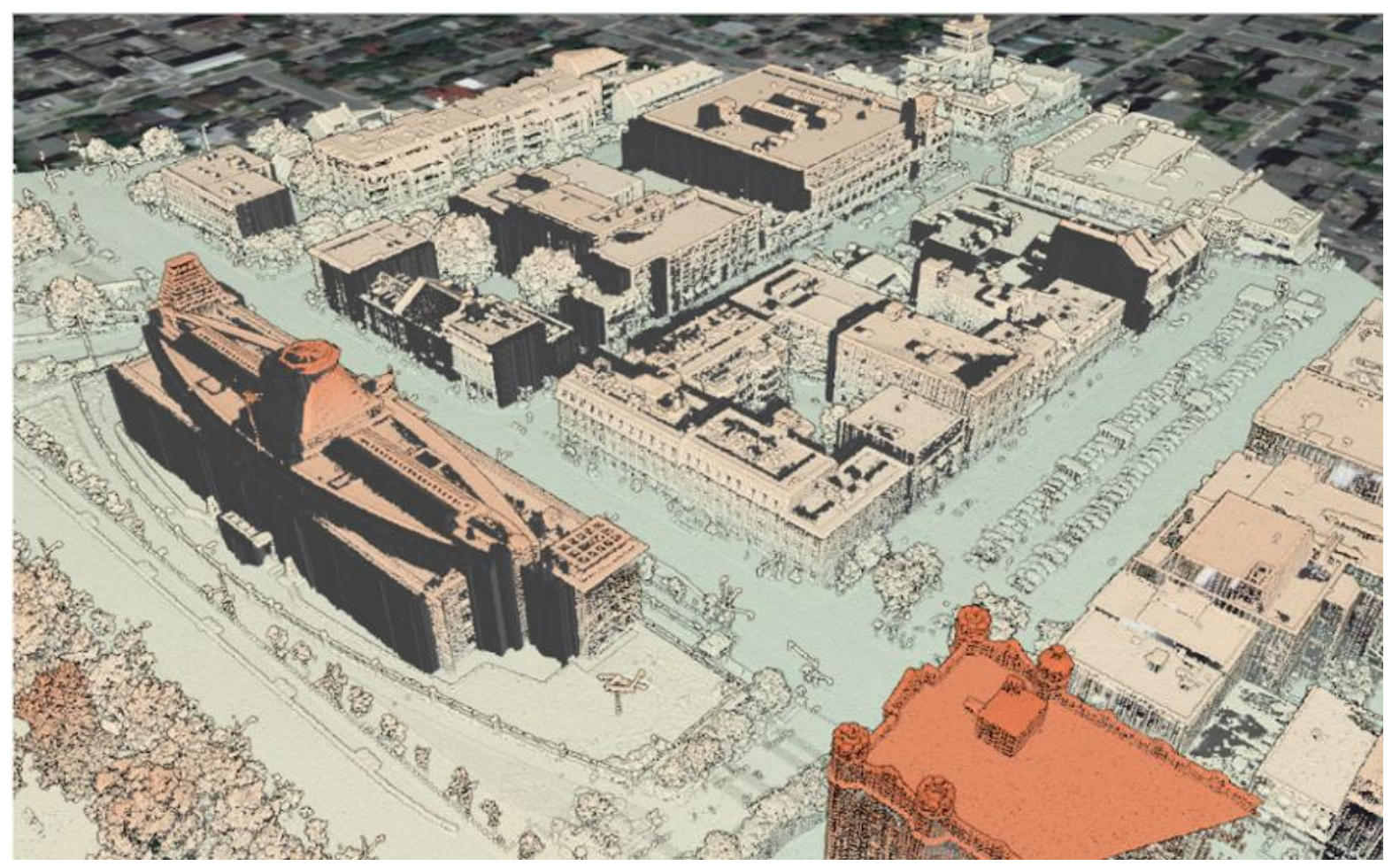

Fig. 4. Displayed results of modeling urban environment within ELiT UC sample 1

generated from point clouds have been proved to be the most efficient data for automated extraction of buildings in densely built-up parts of an urban territory, then a municipal manager should apply to this data in a broad application variety. Within this common municipal planning use-case for smart cities various combinations of these four thematic layers extracted and classified (ground, vegetation, buildings, other man-made objects) become the subjects of other use cases.

One of this use cases corresponds to $\underline{E L i T U C}$ sample 2 in the same area of common urban planning. This UC provides the modeled comparison of various urban environments, what is impossible to complete otherwise than with geoinformation tools (Fig. 5). Using open source LiDAR data from the USGS (the United States Geological Society) website (https://usgs.entwine.io) we have compared with ELiT urban areas of four U.S. cities, attempting to make a preliminary estimate how far is each of them from the "smart urban environments". There is in each of compared units a clear geoinformation context for a new housing or infrastructure development in the area. In this way, it can be visualized for urban planners not just the merits of a new feature allocation, but how it interacts with all other features that already exist.
Obviously, this comparison cannot answer more or less exactly on the question: which from four cities has gone farther on its way to the "smart urban environment", because this would need a huge processed volume of massive attributive data. Nonetheless, by developing the relevant pattern recognition technique some approximation of such answer "on-fly" can be done even with the existing $E L i T$ functionalities. Evidently, this pattern recognition can be substantially enhanced, if it takes into account human-environment-technological interactions, which have been collected using human and technical sensors.

ELiT UC sample 3 seems to be similar to the first one of common urban planning, but focuses on the urban asset inspection domain (Fig. 6). For example, this urban asset inventory task should accomplish a team of municipal engineers in Montreal, Canada. These professionals have to find a quite fast and cost-effective approach to estimate the existing state of urban environment and its deviation from a "smart template", because up to now they have access to an out-of-dated city cadaster only.

This visualization expedites to obtain a view of a combination of the high quality geometric / topological building models with their semantic attributes (refer to Fig. 3). Reaching this goal means the 


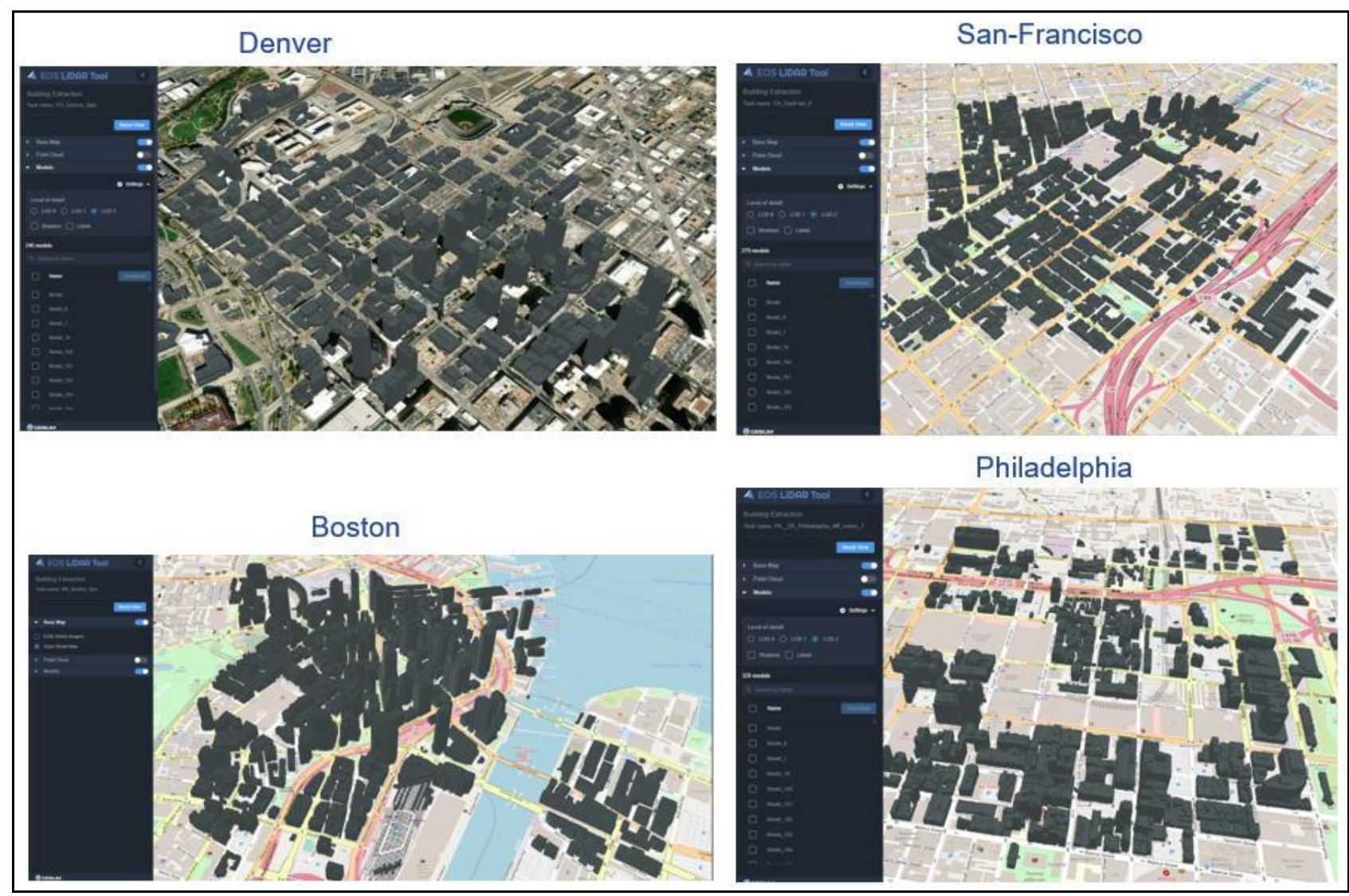

Fig. 5. Displayed results of modeling comparison of four urban environments within ELiT UC sample 2

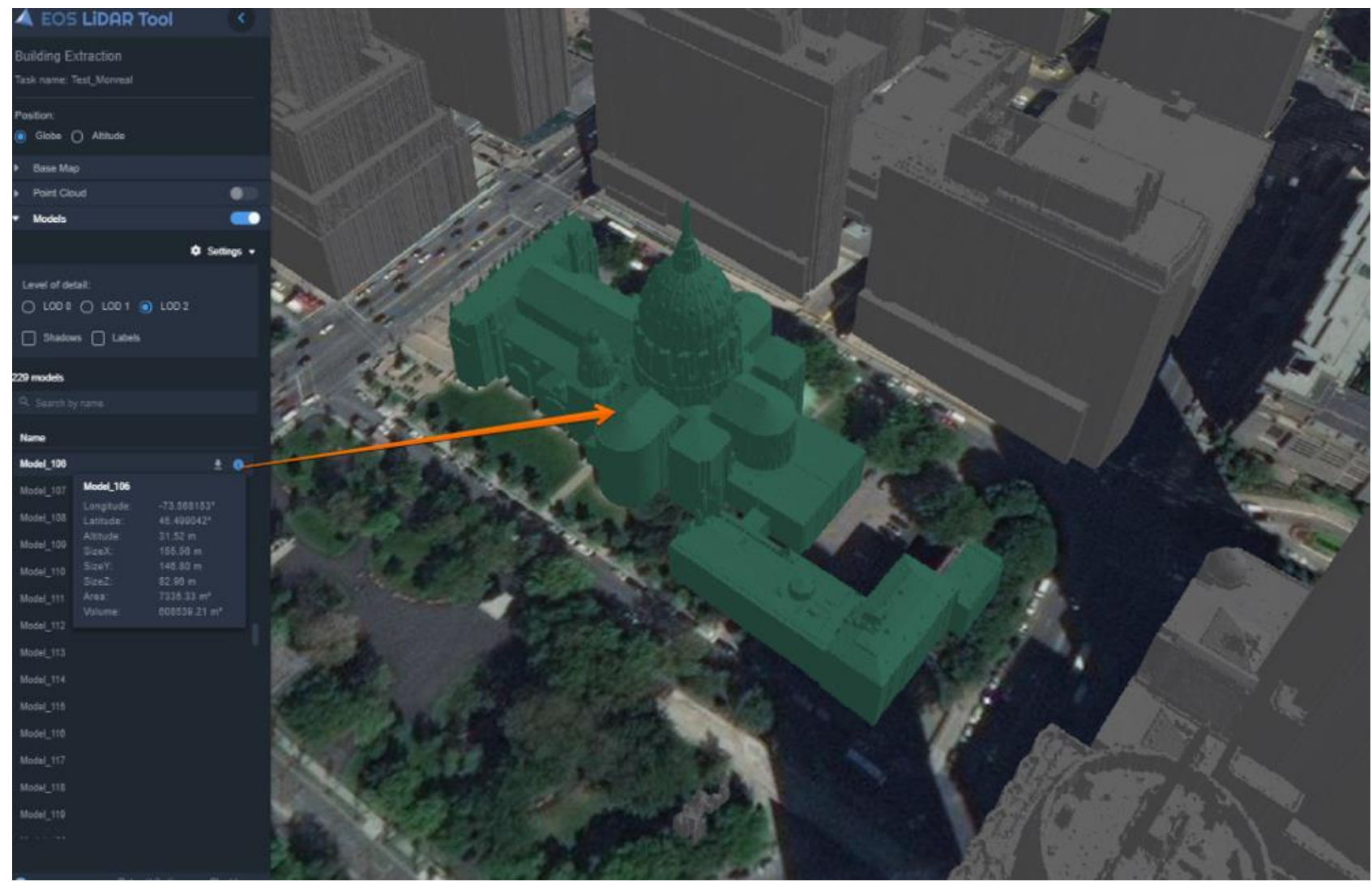

Fig. 6. A complicated building model with its attributive information within ELiT UC sample 3 
accomplishment of an urban asset inventory task. This model coupling for the particular AOI helps in better understanding the city situation over a 3D Scene, its already mentioned deviation from "smart template" and does this easier, than with routine 2D paper, or even in comparison with standardized digital maps. Municipal users-practitioners can estimate building locational design, its envelope, and local urban environment for better positioning the perspective housing constructions. What is more, any coming alterations in design and constructions can be estimated, while direct impact on its surroundings of any existing or future building can be evaluated by selecting of any particular model and getting its geometric and semantic attributes (refer to Fig. 6).

A web-visualization is a standard procedure for tourists and investors attraction to a certain city (Fig. 7). In general, the visualization and display of urban environment can be effective for displaying the particular locations of cognate clients, spatial distribution of the market demands for locationalbusiness services, as well as the availability of free space for further housing development as in this ELiT UC sample 4 (refer to Fig. 7) (Washington, D.C., open source data referred to above). This modeling of urban surroundings can hardly be overvalued taking into account a task of simulating "the Smart Urban Environment", because the latter definitely characterized by complicated social and infra- structural operational configurations and by high population density. This web-modeling and display already presented on illustrations in this paper section actually merge both spatial, and temporal scales of urban environment in this way producing not only maps and scenes for municipal planning purposes, but also - the spatiotemporal context [42] for the Smart City concept.

ELiT UC sample 5 directly relates to the $3 D$ City Automated Cadaster. Many municipalities have been focusing in recent years on developing the real estate registration just in a 3D Cadaster to provide visions of complex property structure, including vertical belongings in buildings to different owners and underground infrastructure (e.g., tunnels, cables, and pipelines, parking lots - Fig. 8).

There are more than one seminal reference in the literature, that understanding the smart city essence is understanding the structure of topology and geometry of its coupled networks [26, 42, 44]. If we effectively model technological networks, as it illustrated above, we can bind to these modeled results probable associations of numerous humanenvironmental-technological interactions that take place in a Smart City area and outline a general geospatial basis, which should be taken as a fundamental for an urban decision support system.

Conclusion, future research and developments. The importance of discussing, how new approaches and techniques in urban remote sensing

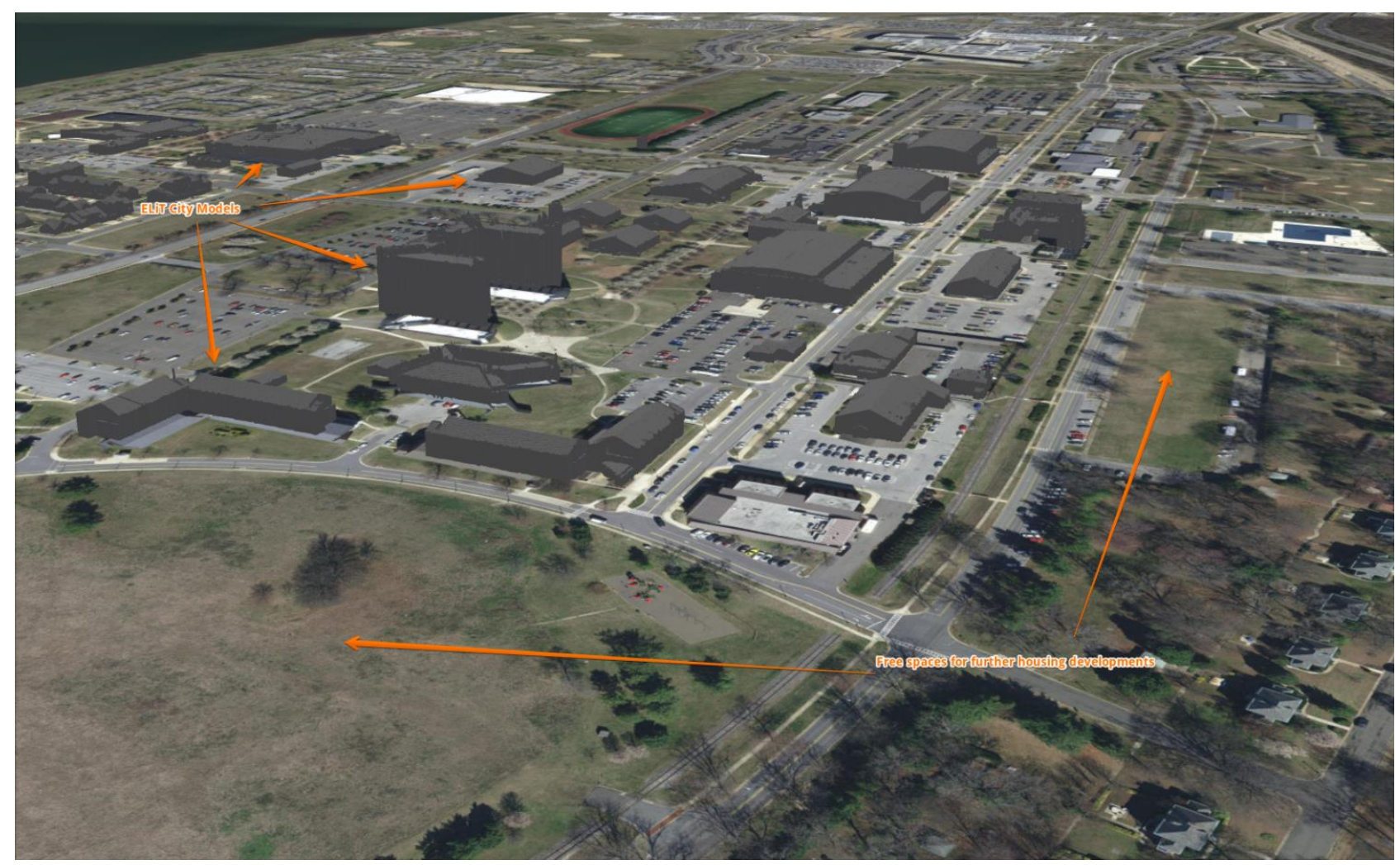

Fig. 7. Modeling and display of urban environment: the detection of free space for the further housing development within ELiT UC sample 4 


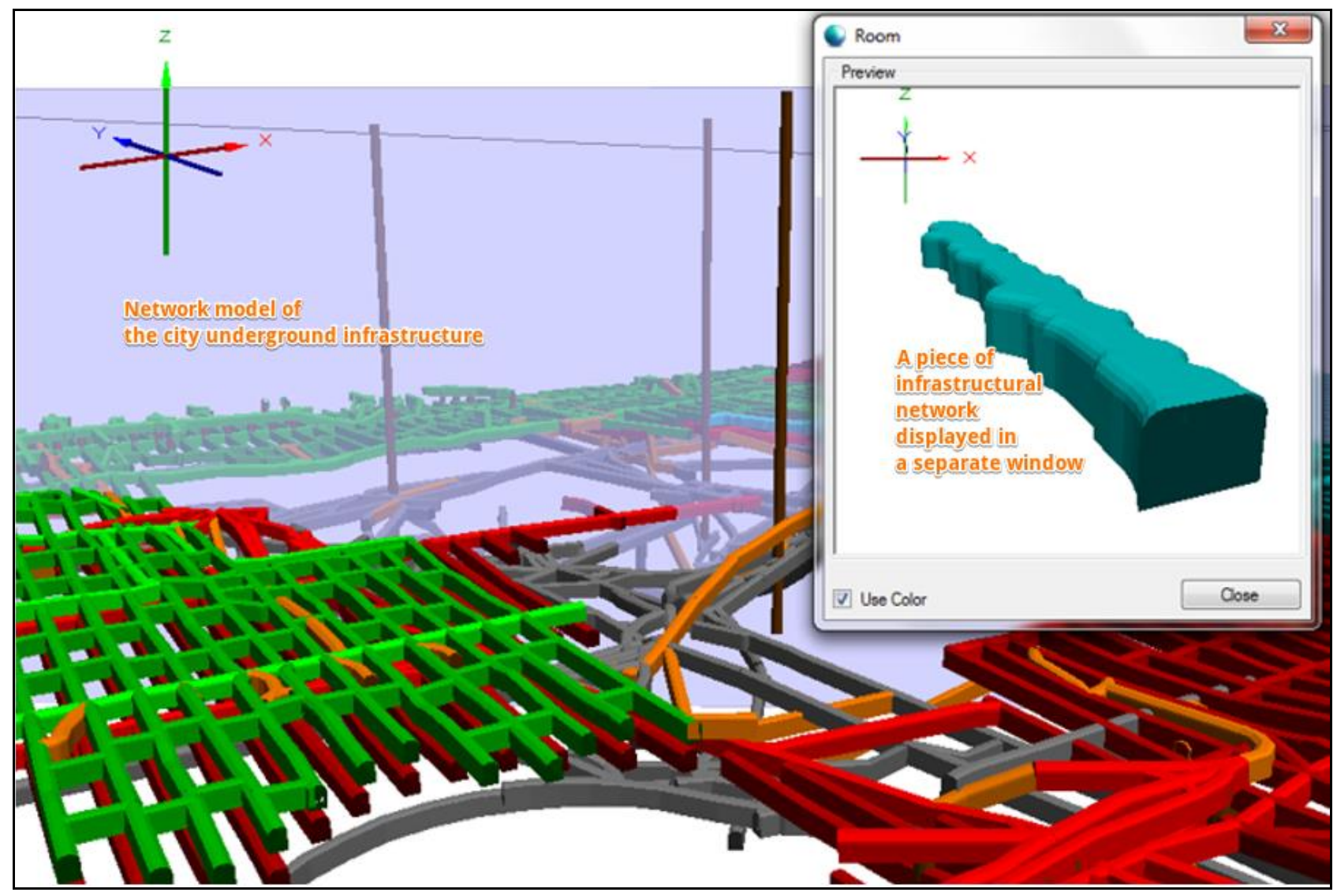

Fig. 8. Modeling and display of underground urban environment with existing infrastructural networks within ELiT UC sample 5 (the interface of ElitCore desktop software)

can contribute to the development of smart cities, is more than evident. In our paper we have attempted to integrate the definitely new ideas within the geospatial perspective of the Smart City concept with LiDAR monitoring and measuring of urban environment and with a number of other relevant procedures within an operational URS / LiDAR / GISworkflow. The concern remains as to whether or not such integration expedites the Smart City implementation into a real practice. To transform this concern into sustainable awareness we have to summarize those issues outlined in this text above, which contribute to the merits of using Urban Remote Sensing with LiDAR for the development of Smart Cities:

- Three basic assumptions and five critically examined key elements of the Smart City concept within its geospatial perspective have been delineated;

- This geospatial perspective is opened by the spatiotemporal context of urban information, and this circumstance may cause different functional configurations of an UDSS;

- A category of the "Smart Urban Environment" has been introduced within the whole hierarchy of the series of environments in the Smart City's UGS ontological model, while the urboge- osystemic approach has been proved to be an only tool for delineation of such hierarchy;

- A definition of a Smart City has been done from the point of view of the urbogeosystemic approach;

- Five basic domains of using LiDAR in Urban Remote Sensing have been outlined as well as three key advantages of this approach have been emphasized;

- An operational URS / LiDAR / GISworkflow has been described within the approach of URS for massive data mining / city analytics;

- Six those relevant to urban data for smart cities issues have been underlined, which strongly correspond to the geospatial perspective of the SCC; these issues have been put into compliance with three key subject areas considered in this paper;

- The whole framework of the URS data mining has been divided for three steps mandatory for any relevant use case development by software tools;

- The functionality and user's interface of the original family of products for LiDAR data processing and 3D city model generation have been introduced by few descriptions of relevant use cases for Smart Cities. 
The further key research and developments may be within the trend of the urban geoinformation space creation, what has been already mentioned in this text earlier. The ELiT 3D Geo-Database (GDB) Unit will be a mandatory key component of the urban decision support system, while both are included into the geoinformation space for smart cities. This GDB may be a derivation of the rational database schema. A geodatabase for storing and managing ELiT 3D city models stands on the CityGML approach and takes a certain place in a general oper- ational workflow (refer to Fig. 2). A GDB would support geometric, semantic, and thematic properties and attributes, taxonomies and aggregations. Its key feature, the city features, represents spatial, georeferenced, geometric entities. Specialized classes of urban features would include buildings, green areas, infrastructure spaces, transportation networks, streets of different ranks, water bodies, vegetation of different belts. This GDB will be implemented as an independent unit of the UDSS, while another unit of this system will support an option of visualization.

\section{References}

1. United Nations. Department of Economic and Social Affairs. - 2018 Revision of World Urbanization Prospects [Electronic resource]. - Режим доcmyny: https://www.un.org/development/desa/publications/2018-revision-ofworld-urbanization-prospects.html

2. Dobbs R. Urban World: Mapping the Economic Power of Cities [Tekcm] / Dobbs R., Smit S., Remes J. [and other]. - McKinsey Global Institute, 2011 [Electronic resource]. - Режuм достуny: https://www.mckinsey.com/featured-insights/urbanization/urban-world-mapping-the-economic-power-of-cities

3. Weng $Q$. Remote sensing for urbanization in tropical and subtropical regions-Why and what matters? [Text] / Q. Weng. // Remote Sensing of Impervious Surfaces in Tropical and Subtropical Areas. Boca Raton /Zhang, H., Lin, H. Zhang, Y., Q. Weng (Editors). - FL: CRC Press/Taylor \& Francis, 2015 - P. 17-22.

4. GEO Group on Earth Observation. Earth Observations for the Benefits of Humankind [Electronic resource]. GEOSS Portal, 2019. - Режим docmyny: http://www.earthobservations.org/index.php

5. Weng Q. Remote Sensing for Sustainability [Text] /Q. Weng. - Boca Raton, FL: CRC Press/Taylor \& Francis, 2016. - $366 \mathrm{pp}$.

6. Group on Earth Observations. The GEO 2016-2025 Strategic Plan: Implementing GEOSS - [Electronic resource]. - 2016 - Режим достyny: https://www.earthobservatio ns.org/geoss_wp.php

7. Kostrikov S.. Geoinformation approach to the urban geographic system research (case studies of Kharkiv region) [Text] / S. Kostrikov, L. Niemets, K. Sehida [and other] // Вісник Харківського національного університету імені В. Н. Каразіна, серія "Геологія. Географія. Екологія". - Вип. 49. - Х.: ХНУ, 2018. - C. 107-121.

8. UNEP. Visions for Change. Recommendations for Effective Policies on Sustainable Lifestyles [Electronic resource] // UNEP Division of Technology, Industry \& Electronics, 2019. - 82 p. - Режим доступy: file:///K:/Texts/Paper_2019/Smart_City_Paper/Sources_Our_Paper/Vision_For_Chnage.pdf

9. Henard E. The Cities of the Future /E. Henard [Electronic resource] // Royal Institute of British Architects. Town Planning Conference. - London, 10-15 October 1910. - Transactions, 1911. - P. 345-367. - Pежим достуny: http://urbanplanning.library.cornell.edu/DOCS/henard.htm

10. Saarinen E. The City: Its Growth, Its Decay, Its Future [Text] / E. Saarinen. - New York: Reinhold Publishing Corporation, 1943. - $236 p$.

11. Eremia M. The Smart City Concept in the $21^{\text {st }}$ Century [Text] / Eremia M., Toma L., Sanduleac M. // Procedia Engineering. - 2017. - Vol. 181. - P. 12-19.

12. Mitchell W. IBM, Smarter Cities - Overview [Electronic resource]. - 2019. - Режим достуny: http://www.ibm.com/smarterplanet/us/en/smarter_cities/overview.

13. Deakin M. Smart Cities. Governing, modeling and analyzing the transition [Text] / M. Deakin (Editor). - NY: Routledge, 2014. - 210 p.

14. Kostrikov S. Three Key Processing Functionalities of the EOS LiDAR Tool / S. Kostrikov, D. Bubnov, A. Kostrikova, R. Pudlo [Text] // Technical Session: LiDAR Data Processing. - Proceedings of $39^{\text {th }}$ Asian Conference on Remote Sensing, 15-19 October 2018, Renaissance Kuala Lumpur Hotel. - 2018. - P. 406.

15. Nam T., Pardo T.A. Smart City as Urban Innovation: Focusing on management, Policy, and Context [Text] / T. Num, T.A. Pardo // ICEGOV Conference, September 26-28, 2011, Tallinn, Estonia. - 2011. - P. $185-194$.

16. Giffinger R. Smart Cities Ranking: An Effective Instrument for the Positioning of Cities? [Text] /R. Giffenger, H. Gudrun //ACE: Architecture, City and Environment. - 2010. - Vol. 4. - No 12. - P. 7-25.

17. Hall R. E. The vision of a smart city / R.E. Hall // Proceedings of the 2nd International Life Extension Technology Workshop, Paris, France, September 28 [Electronic resource]. - 2000. - Режим доступy: https://www.osti.gov/servlets/purl/773961/

18. Hartley J. Innovation in governance and public services: Past and present [Text] /J. Hartley // Public Money \& Management. - 2005. - Vol. 25. - No 1. - P. 27-34.

19. Toppeta D. The Smart City Vision: How Innovation and ICT Can Build Smart, "Livable”, Sustainable Cities [Electronic resource] // The Innovation Knowledge Foundation, 2010. - Режим доступy: http://www.thinkinnovation.org/file/research/23/en/Toppeta_Report_005_2010.pdf 
20. Washburn, D. Helping CIOs Understand "Smart City" Initiatives: Defining the Smart City, Its Drivers, and the Role of the CIO / D. Washburn, U. Sindhu, S. Balaouras [and other] [Electronic resource]. - Cambridge, MA: Forrester Research, Inc.- 2010. - Pежuм достуny: http://public.dhe.ibm.com/partnerworld/pub/smb/smarterpla net/forr_help_cios_und_smart_city_initiatives.pdf

21. Manson A. Smart cities concept and challenges: Bases for the assessment of smart city projects [Electronic resource] / A. Manson // Proceedings of 2015 International Conference on Smart Cities and Green ICT Systems (SMARTGREENS). - 2015. - Режuм достуny: https://ieeexplore.ieee.org/stamp/stamp.jsp?tp=\&arnumber= 7297938

22. Bradford N. Place matters and multi-level governance: Perspectives on a new urban policy paradigm [Text] /N. Bradford // Policy Options. - 2004. - Vol. 25. -No. 2. - P. 39-45.

23. Sylvie D. GeoSmartCity: geomatics contribution to the Smart City [Text] / D. Sylvie, M.A. Doran // Proceedings of 14th annual International Conference on digital Government research: From e-Government to Smart Government, ACM, 2013. - P. 65-71.

24. Li Y. Analysis of the challenges and solutions of building a smart city [Text] / Li Y., Liu A. // Proceedings of 2013 International Conference on Construction and Real Estate Management (ICCREM), ASCE, Reston, VA, 2013. - P. 1511-1515.

25. Криничанский К.В. Современный российский город в свете тенденций урбанистического мира [Текст] / К.В. Криничанский // Региональная экономика: теория и практика. - 2013. - Bbın. 32 (311) - C. 2-13.

26. Batty M. Smart cities of the future [Text] / M. Batty, K. Axhausen, F. Giannotti [and other] // The European Physical Journal. - 2012. - Vol. 214. - P. 482-518.

27. Fu P. A time series analysis of urbanization induced land use and land cover change and its impact on land surface temperature with Landsat imagery [Text] /P. Fu, Q. Weng // Remote Sensing of Environment. - 2016. - Vol. 175. - No 4. - P. 205-214.

28. Batty M., The size, scale, and shape of cities [Text] /M. Batty // Science. - 2008. - Vol. 319 (5864). - P. 769-771.

29. Grimm N.B. Global change and the ecology of cities [Text] / N.B. Grimm, S.H. Fraeth, N.E. Golubiewski [and other] // Science. - 2008. - Vol. 319 (5864). - P. 756-760.

30. Potere D. A critical look at representations of urban areas in global maps [Text] / D. Potere, A. Schneider // GeoJournal. - 2007. - Vol. 69. - No. 1. - P. 55-80.

31. Miyazaki $H$. An automated method for global urban area mapping by integrating ASTER satellite images and GIS data [Text] / H. Miyazaki H., Shao X., Iwao K., Shibasaki R. // IEEE Journal of Selected Topics in Applied Earth Observations and Remote Sensing. - 2013. - Vol. 6 (2). - P. 1004-1019.

32. Wieland $M$. Large-area settlement pattern recognition from Landsat-8 data. M. Wieland, M. Pittore // ISPRS Journal of Photogrammetry and Remote Sensing. - 2016. - Vol. 119. - P. 294-308.

33. Dong P. LiDAR Remote Sensing and Applications [Text] / P. Dong, Q. Chen. - Boca Raton: CRC Press, 2018. $246 \mathrm{p}$.

34. Giannotti F. Unveiling the complexity of human mobility by querying and mining massive trajectory data [Text] $/$ F. Giannotti, M. Nanni, D. Pedreschi [and other] // The International Journal on Very Large Data Bases. - 2011. Vol. 20. - No 5. - P. 695-719.

35. Song C. Modelling the scaling properties of human mobility [Text] / C. Song, T. Koren, P. Wang [and other] // Nature Physics. - 2010. - Vol. 6. - P. 818-823.

36. Song C. Limits of predictability in human mobility [Text] / C. Song, Z. Qu, N. Blumm [and other] // Science. 2010. - Vol 327. - P. 1018-1021.

37. Felbier A. The global urban footprint; processing status and cross comparison to existing human settlement products [Text] / A. Felbier, T. Esch, W. Heldens [and other] // IEEE Geoscience and Remote Sensing Symposium. 2014. - P. 4816-4819.

38. Lazaroiu G.C. Definition methodology for the smart cities model [Text] / G. C. Lazaroiu, M. Roscia // Energy. 2012. - Vol. 47. - P. 326-332.

39. Desfor G. Nature and the City: Making Environmnetal Policy in Toronto and Los Angeles [Text] / G. Desfor, R. Keil. - Tucson: the University of Arizona Press, 2004. - 269 p.

40. Gil-García J. R. E-government success factors: Mapping practical tools to theoretical foundations [Text] / J.R. Gil-García, T.A Pardo // Government Information Quarterly. - 2005. - Vol. 22. - No 2. - P. 187- 216.

41. Eger J. M. Smart growth, smart cities, and the crisis at the pump a worldwide phenomenon [Text] /J.M. Eger // IWays. - 2009. - Vol. 32. - No. 1. - P. 47-53.

42. Sagl G. Contextual sensing: integrating contextual information with human and technical geo-sensor information for Smart Cities [Text] / G. Sagl, T. Blashker // Sensors. - 2015. - Vol. 15. - P. 17013-17035.

43. Resch B. Live geography: Interoperable geo-sensor webs facilitating the vision of digital earth [Text] / Resch B., Blaschke T., Mittlboeck M. // International Journal of Advanced Network Services. - 2010. - Vol. 3. - P. $323-332$.

44. Talari S. A review of Smart Cities based on the Internet Of Things concept [Text] / S. Talari, M. Shafie-khah, P. Siano // Energies. - 2017. - Vol. 421. - No 10. - P. 3-26.

45. Merbitz H. Gis-based identification of spatial variables enhancing heat and poor air quality in urban areas [Text] / H. Merbitz, M. Buttstädt, S. Michael // Applied Geography. - 2012. - Vol. 33. - P. 94-106. 
46. Sagl G. Ubiquitous geo-sensing for context-aware analysis: Exploring relationships between environmental and human dynamics [Text] / G. Sagl, T. Blaschke, E. Beinat // Sensors. - 2012. - Vol. 12. - P. 9835-9857.

47. Lukowicz P. Beyond context awareness [Text] / P. Lukowicz, T. Choudhury, H. Gellersen // IEEE Pervasive Computing. - 2011. - Vo. 10. - P. 15-17.

48. Schmidt A. There is more to context than location [Text]. / A. Schmidt, M. Beigl, H.-W. Gellersen // Computer Graphics. - 1999. - Vol. 23. - P. 893-901.

49. Naphade M. Smarter cities and their innovation challenges [Text] / M. Naphade, G. Banavar, C. Harrison [and other]. - 2011. - Vol. 44. -No 6. - P. 32-39.

50. Костріков C.B. Програмне забезпечення ГIC для LiDAR-технологї дистаниійного зондування в цілях аналізу урбогеосистем [Текст] / С.В. Костріков, Д.Л. Кулаков, К.Ю. Сегіда // Проблеми безперервної географічної освіти і картографії-ГІС-форум'14. Збірник наукових праць - 2014. - Bun. 19. - C. 45-52.

51. Філатов В.М., Костріков С.В. Щодо розгляду окремих аспектів конщепщії «Розумне Місто» у суспільногеографічній площині [Текст] / В.М. Філатов, С.В. Костріков // РЕГІОН-2019: Суспільно-географічні аспекти. Матеріали Міжнародної науково-практичної конферениії студентів, аспірантів та молодих науковиів (м. Харків, 11-12 квітня 2019 р.). - Харків, 2019. - С. 108-111.

52. Костріков С.В. Аналіз дворівневих урбогеосистем через засоби ГІС [Текст] / С.В. Костріков, О.С. Чуєв // Вісник ХНУ.-Вип. 44 - Геологія- Географія-Екологія. - Харків: Видавництво ХНУ, 2016. - С. 98-109.

53. Безрук В.А., Костріков С.В., Чуєв А.С. ГІС-аналіз функиї урбогеосистеми з метою оптимізації розміщення закладів громадського харчування (на прикладі м. Харків) [Текст] / В.А. Безрук, С.В. Костріков, А.С. Чуєв // Часопис соціально-економічної географії. - Bun. 21 (2), 2016. - C. 91-101.

54. Bourne L.S. Simmons J.W. (Editors), Systems of Cities: Readings on Structure, Growth, and Policy [Text] / L.S. Bourne, J.W. Simmons - Oxford: Oxford University Press, 1978. - 565 p.

55. Torregrosa A. Smart City concepts, Challengers and Projects [Text] /A. Torregrosa, M. Martin // $1^{\text {st }}$ ASCIMER Workshop. - EIBURS, 2014. - P. 198-214.

56. Hancke G.P. The role of advanced sensing in Smart Cities [Text] / G. Hancke, B. Silva, G. Hancke Jr // Sensors. 2013. - Vol. 13-P. 393-425.

57. Lazaroiu G.C. Definition methodology for the smart city model [Text] / G.C. Lazaroiu, M. Roscia . - 2012. - Vol. 47. - P. 326-332.

58. Naphade M. Smarter cities and their innovation challenges [Text] / M. Naphade, G. Banavar, G. Harrison [and other] // Computer . - 2011. - Vol. 44(6). - P. 32-39.

59. Potere D. Mapping urban areas on a global scale: Which of the eight maps now available is more accurate [Text] / D. Potered, A. Schneider, A. Shlomol [and other] // International Journal of Remote Sensing. - 2009. - Vol. 30 (24). - P. 6531-6558.

60. Rathore M.M. Urban planning and building smart cities based on the Internet of Things using Big Data analytics [Text] / M.M. Rathore, A. Ahmad, A. Paul [and other] // Computer Networks. - 2016. - Vol. 101. - P. 63-80.

61. Allwinkle S. Creating smart-er cities: An overview [Text] / S. Allwinkle, P. Cruickshank // Journal of Urban Technologies. - 2011. - Vol. 18. - P. 1-16.

62. Kostrikov S. Three Key EOS LiDAR Tool Functionalities for Urban Studies [Text] / S. Kostrikov, R. Pudlo, A. Kostrikova // Full Paper Proceeding of ACRO'2018, Kuala Lumpur, Malaysia. - Technical Session: LiDAR Data Processing, 2018. - Vol. 3. - P. 1676-1685.

63. Brenner C. Building reconstruction from images and laser scanning [Text] / C. Brenner // International Journal of Applied Earth Observation and Geoinformation. - 2005. -Vol. 6. - No3. - P. 187-198.

64. Dorninger P. A comprehensive automated 3D approach for building extraction, reconstruction, and regularization from airborne laser scanning point clouds [Text] / P. Dorninger, N. Pfeifer // Sensors. - 2008. - Vol. 8. - No 11. - P. 7323-7343.

65. Haala N. An update on automatic $3 D$ building reconstruction // ISPRS Journal of Photogrammetry and Remote Sensing [Text]/ N. Haala, M. Kada. - 2010. - Vol. 65. - No 6. - P. 570-580.

66. Musialski P. A survey of urban reconstruction [Text] / P. Musialski, P. Wonka, D.G. Aliaga [and other] // Computer Graphics Forum. - 2013. - Vol. 32. - No 6. - P. 146-177.

67. Wang R. 3D building modeling using images and LiDAR: a review [Text] / R. Wang // International Journal of Image and Data Fusion. - 2013. - Vol. 4. - No 4. - P. 273-292.

68. Ackermann F. Airborne laser scanning - present status and future expectations Text] / F. Ackermann // Journal of Photogrammetry \& Remote Sensing. - 1999. - Vol. 54. - No 1. - P. 64-67.

69. Sampath A. Segmentation and reconstruction of polyhedral building roofs from aerial LIDAR point clouds [Text] / A. Sampath, J. Shan // IEEE Transactions on Geoscience and Remote Sensing. - 2010 - Vol. 48. - No. 3. - P. 15541567.

70. Vosselman G. 3D building model reconstruction from point clouds and ground plans [Text] / G. Vosselman, S. Dijkman // IAPRS. - 2001. - Vol. 34 (3W4). - P. 37-43.

71. Yan W.Y. Urban land cover classification using airborne LiDAR data: A review [Text] / W.Y. Yan, A. Shaker, N. El-Ashmawy // Remote Sensing of Environment. - 2015. - Vol. 158. - P. 295-310.

72. Pu S. Knowledge based reconstruction of building models from terrestrial laser scanning data [Text] / S. Pu, G. Vosselman // ISPRS Journal of Photogrammetry and Remote Sensing. - 2009. - Vol. 64. - P. 575-584. 
73. Orthuber E. 3D building reconstruction from Lidar point clouds by adaptive dual contouring [Electronic resource]/ E. Orthuber, J. Avbelj // ISPRS Annals of the Photogrammetry, Remote Sensing and Spatial Information Sciences, Vol. II- W4.- PIA15+HRIGI15-Joint ISPRS conference 2015, 25-27 March, 2015, Munich, Germany - 2015. Режим достуny: https://pdfs.semanticscholar.org/d99b/d10b290a18a8070466a37f463c0886955f63.pdf

74. Biljecki F. Applications of 3D City Models: State of the Art Review [Text] / F. Biljecki, J. Stoter, H. Ledoux [and other] // ISPRS International Journal of Geo-Information. - 2015. - Vol. 4. - P. 2842-2889.

75. Урбаністична Україна: в епіцентрі просторових змін. Колективна монографія [Текст] / К. Мезенщев, Я. Олійник, Н. Мезенцева (редактори). - Киї: Фенікс, 2017. - 438 с.

76. Акатов Н.Б. Проект «Умный Город»: предпосылки реализуемости и успешности [Текст] /Н.Б. Акатов, С.В. Толчин, П.В. Молянов [и другие] // Вестник ПНИПУ. Сочиально-экономические науки - 2018. - № 2. C. 116-126.

77. Костріков С. Веб-застосування ELiT - програмне забезпечення для моделювання $і$ аналізу міського середовища [Текст] / С. Костріков, Д. Бубнов, А. Кострікова, Р. Пудло // Збірник матеріалів конференції «ГІСФорум»-2018»-Харків, $2018-$ - . 56-59.

78. Brail R.K. Planning Support Systems for Cities and Regions [Text] / R.K. Brail (Editor). - Lincoln Institute of Land Policy, Cambridge, MA. - 2008. - 312 p.

79. Dwivedil M. New horizons in planning Smart Cities using LiDAR technology [Text] / M. Dwivedil, A. Uniyal, R. Mohan // International Journal of Applied Remote Sensing and GIS. - 2015. - Vol. 2. - No 1. - P. 40-50.

80. Hodgson M.E. Synergistic use of LiDAR and color aerial photography for mapping urban parcel imperviousness [Text] / M.E. Hodgson, J.R. Jensen, J.A. Tullis [and other] // Photogrammetric Engineering \& Remote Sensing. 2003. - Vol. 69. - No.9. P. 973-980.

81. Germaine K. A. Delineation of impervious surface from multispectral imagery and LiDAR incorporating knowledge based expert system rules [Text] / K.A. Germaine, M.C. Hung // Photogrammetric Engineering \& Remote Sensing. - 2011. - Vol. 77. - No 1. - P. 75-85.

82. Garcia-Gutierrez J. Automatic environmental quality assessment for mixed-land zones using LiDAR and intelligent techniques [Text] /J. Garcia-Gutierrez, L. Goncalves-Seco, J.C. Riquelme-Santos // Expert Systems with Applications. - 2011. - Vol. 38. - No 6. - P. 6805-6813.

83. Stal C. Airborne photogrammetry and LiDAR for DSM extraction and $3 D$ change detection over an urban areaa comparative study [Text] / C. Stal, F. Tack, P. De Maeyer [and other] // International Journal of Remote Sensing. - 2013. - Vol. 34. - No 4. - P. 1087-1110.

84. Teo, T.-A., Shih, T.-Y. LiDAR-based change detection and change-type determination in urban areas [Text] / T.A. Teo, T.-Y. Shih // International Journal of Remote Sensing. - 2013. - Vol. 34. - No 3. - P. 968-981.

85. Khoshelham K. Performance evaluation of automated approaches to building detection in multisource aerial data [Text] / K. Khoshelham, C. Nardinocchi, E. Frontoni [and other] // ISPRS Journal of Photogrammetry and Remote Sensing. - 2010. - Vol. 65. - P. 123-133.

86. Dong L. A comprehensive review of earthquake-induced building damage detection with remote sensing techniques[ Text] / L. Dong,, J. Shan // ISPRS Journal of Photogrammetry and Remote Sensing. - 2013. - Vol. 84. - P. 85-99.

87. Baltsavias E. P. Object extraction and revision by image analysis using existing geodata and knowledge: Current status and steps towards operational systems [Text] / E.P. Baltsavias // ISPRS Journal of Photogrammetry and Remote Sensing. - 2004. - Vol. 58. - P. 129-151.

88. Vu T.T. Multi-scale solution for building extraction from LiDAR and image data [Text] / T.T. Vu, F. Yamazaki, M. Matsuoka // International Journal of Applied Earth Observation and Geoinformation. - 2009. - Vol. 11. - P. 281289.

89. Zhang L., Xи T., Zhang J. Building extraction based on multiscale segmentation [Text] / L. Zhang, T. Xu, J. Zhang // 5th International Congress on Image and Signal Processing (CISP), October 16-18, 2012. - 2012. - P. 657-661.

90. Perron J.T. Formation of evenly spaced ridges and valleys [Text] / J.T. Perron, J.W. Kirchner, W.E. Dietrich / Nature. - 2009. - Vol. 460. - P. 502-505.

91. Glenn N.F. Analysis of LiDAR-derived topographic information for characterizing and differentiating landslide morphology and activity [Text] / N.F. Glenn, D.R. Streutker, D.J. Chadwick [and other] // Geomorphology. - 2006. - Vol. 73. - P. 131-148.

92. Schulz W.H. Landslide susceptibility revealed by LIDAR imagery and historical records, Seattle, Washington [Text] / W.H. Schulz // Engineering Geology. - 2007. - Vol. 89. - P. 67-87.

93. Dong P. A framework for automated assessment of post-earthquake building damage using geospatial data [Text] / P. Dong, H.D. Guo // International Journal of Remote Sensing. - 2012. - Vol. 33. - P. 81-100.

94. Zhu Q. Research and practice in three-dimensional city modeling [Text] / Q. Zhu, M. Hu, Y. Zhang // Geo-Spatial Information Science. - 2009. - Vol. 12. - P. 18-24.

95. Giannotti F. Mobility, Data Mining and Privacy: Geographic Knowledge Discovery [Text] / F. Giannotti, D. Pedreschi. - Springer, Berlin. - 2008. - 412 p.

96. Zhang X. A linear dirichlet mixture model for decomposing scenes: Application to analyzing urban functional zonings [Text] / X. Zhang, S. Du // Remote Sensing of Environment. - 2015. - Vol. 169. - P. 37-49. 
97. Wen D. A novel automatic change detection method for urban high resolution remotely sensed imagery based on multiindex scene representation [Text] / D. Wen, X. Huang, L. Zhang // IEEE Transactions on Geoscience and Remote Sensing. - 2016. - Vol. 54. - No 1.- P. 609-625.

98. Kabolizade M. An improved snake model for automatic extraction of buildings from urban aerial images and LiDAR data [Text] / M. Kabolizade, H. Ebadi, S. Ahmadi // Computers, Environment and Urban System. - 2010. Vol. 34. - P. 435-441.

99. Susaki J. Knowledge-based modeling of buildings in dense urban areas by combining airborne LiDAR data and aerial images [Text] / J. Susaki // Remote Sensing. - 2013. - Vol. 5. - P. 5944-5963.

100. $\mathrm{Ng}$ E. Policies and technical guidelines for urban planning of high-density cities - air ventilation assessment (AVA) of Hong Kong [Text] / E. Ng // Building and Environment. - 2009. - Vol. 44. - No 7. - P. 1478-1488.

UDC 711.433:004.9+004.451+911.3

Sergiy Kostrikov,

Doctor of Sciences (Geography), Professor, Department of Human Geography and Regional Studies,

V. N. Karazin Kharkiv National University, 4 Svobody Sq., Kharkiv, 61022, Ukraine;

EOS Data Analitics Ukraine, LLC, 31 Alchevskyh St., Kharkiv, 61002, Ukraine, e-mail: sergiy.kostrikov@eosda.com, https://orcid.org/0000-0002-4236-8474

\section{URBAN REMOTE SENSING WITH LIDAR FOR THE SMART CITY CONCEPT IMPLEMENTATION}

Introduction of the problem. The paper emphasizes that the key features of the contemporary urban development have caused a number of challengers, which require the innovative technological introductions in urban studies. The research goal of this paper means representing a multifunctional approach, which combines author's urbogeosystem (UGS) theory with the URS (Urban Remote Sensing) technique for LiDAR (Light Detection And Ranging) data processing.

The key elements of the Smart City concept within a geospatial perspective. Three basic assumptions are implied due to the affiliation "a geospatial perspective $\Leftrightarrow$ the Smart City concept" (SCC). The five key elements of the SCC have been outlined: Innovations; Scalability; Data gathering, measuring, and mining; Addressing environmental challengers; Interlink between the smart meter information and the geosensor information.

The urbogeosystemic approach as a tool for simulating the "smart urban environment" - a core node of the Smart City hierarchy. The urbogeosystemic ontological model has been introduced as a trinitytripod (urban citizens, municipal infrastructure, urbanistic processes and phenomena). The "smart urban environment" is a core node of an urbogeosystem.

Processing results of LiDAR surveying technique. With increasing availability of LiDAR data, 3D city models of robust topology and correct geometry have become the most prominent features of the urban environment. Three key advantages of the LiDAR surveying technique have been introduced. The flowchart of the operational URS / LiDAR / GIS workflow for the Smart City implementation has been depicted.

Urban Remote Sensing for data mining / city analytics and the EOS LiDAR Tool. ELiT (EOS LiDAR Tool) software is both a separate web-based (network) generator (an engine) - ELiT Server, and an integrated component of EOS Platform-as-a-Service software - ELiT Cloud. The allied one to these two products is our desktop ElitCore software, that possesses even broader functionality. The paper outlines the whole framework of urban data mining / city analytics relevant to the mentioned applications.

The ELiT software use cases for the Smart Cities. A number of use cases that can be completed with the ELiT software in the common urban planning domain have been described and illustrated. Each from five scenarios presented suggests some unique solution within the frameworks of the SCC implementation.

Conclusion, future research and developments. The completed research results have been summarized. An entity of the urban geoinformation space has been introduced. A geodatabase of ELiT 3D city models has been assigned a mandatory key component of the urban decision support system.

Keywords: LiDAR remote sensing, urban environment, the Smart City concept, interface and functionality of GIS web-application, software use cases, urban decision support system.

\section{References}

1. United Nations. Department of Economic and Social Affairs. (2018). Revision of World Urbanization Prospects. Available at: https://www.un.org/development/desa/publications/2018-revision-of-world-urbanizationprospects.html 
2. Dobbs, R., Smit, S., Remes, J. [and other] (2011). Urban World: Mapping the Economic Power of Cities. McKinsey Global Institute. Available at: https://www.mckinsey.com/featured-insights/urbanization/urban-world-mappingthe-economic-power-of-cities

3. Weng, Q. (2015). Remote sensing for urbanization in tropical and subtropical regions-Why and what matters? Remote Sensing of Impervious Surfaces in Tropical and Subtropical Areas. Boca Raton / Zhang, H., Lin, H. Zhang, Y., Q. Weng (Editors). FL: CRC Press/Taylor \& Francis, 17-22.

4. GEO Group on Earth Observation. (2019). Earth Observations for the Benefits of Humankind. GEOSS Portal. Available at: http://www.earthobservations.org/index.php

5. Weng, Q. (2016). Remote Sensing for Sustainability. Boca Raton, FL: CRC Press/Taylor \& Francis, 366.

6. Group on Earth Observations. (2016). The GEO 2016-2025 Strategic Plan: Implementing GEOSS. Available at: https://www.earthobservatio ns.org/geoss_wp.php

7. Kostrikov, S., Niemets, L., Sehida, K. [and other] (2018) Geoinformation approach to the urban geographic system research (case studies of Kharkiv region) [Text] / S. Kostrikov, L. Niemets, K. Sehida [and other]. Kharkiv National University Bulletin in Geology, Geography, and Ecology, 49, 107-121.

8. UNEP. (2019). Visions for Change. Recommendations for Effective Policies on Sustainable Lifestyles, 82. Available at: file:///K:/Texts/Paper_2019/Smart_City_Paper/Sources_Our_Paper/Vision_For_Chnage

9. Henard, E. (2011). The Cities of the Future. Royal Institute of British Architects. Town Planning Conference. London, 10-15 October 1910, 345-367.Available at: http://urbanplanning.library.cornell.edu/DOCS/henard.htm

10. Saarinen, E. (1943). The City: Its Growth, Its Decay, Its Future. New York: Reinhold Publishing Corporation, 236.

11. Eremia, M., Toma, L., Sanduleac, M. (2017). The Smart City Concept in the $21^{\text {st }}$ Century. Procedia Engineering, 181, 12-19.

12. Mitchell, W. (2019). IBM, Smarter Cities - Overview. Available at: http://www.ibm.com/smarterplanet/us/en/ smarter_cities/overview.

13. Deakin, M. (2014). Smart Cities. Governing, modeling and analyzing the transition. New York: Routledge, 210.

14. Kostrikov, S., Bubnov, D., Kostrikova, A. [and other]. (2018). Three Key Processing Functionalities of the EOS LiDAR Tool. Technical Session: LiDAR Data Processing. Proceedings of $39^{\text {th }}$ Asian Conference on Remote Sensing, 15-19 October 2018, Renaissance Kuala Lumpur Hotel, 406.

15. Nam, T., Pardo, T.A. (2011). Smart City as Urban Innovation: Focusing on management, Policy, and Context. ICEGOV Conference, September 26-28, 2011, Tallinn, Estonia, 185-194.

16. Giffinger, R. Gudrun, H. (2010). Smart Cities Ranking: An Effective Instrument for the Positioning of Cities?. ACE: Architecture, City and Environment, 4 (12), 7-25.

17. Hall, R. E. (2000). The vision of a smart city. Proceedings of the 2nd International Life Extension Technology Workshop, Paris, France, September 28. Available at: https://www.osti.gov/servlets/purl/773961/

18. Hartley, J. (2005). Innovation in governance and public services: Past and present. Public Money \& Management, 25(1), 27-34.

19. Toppeta, D. (2010). The Smart City Vision: How Innovation and ICT Can Build Smart, "Livable”, Sustainable Cities. The Innovation Knowledge Foundation, Available at: http://www.thinkinnovation.org/file/research/23/en/ Toppeta_Report_005_2010.pdf

20. Washburn, D., Sindhu, U., Balaouras, S. [and other] (2010). Helping CIOs Understand "Smart City" Initiatives: Defining the Smart City, Its Drivers, and the Role of the CIO. Cambridge, MA: Forrester Research, Inc. Available at: http://public.dhe.ibm.com/partnerworld/pub/smb/smarterpla net/forr_help_cios_und_smart_city_initiatives.pdf

21. Manson, A. (2015). Smart cities concept and challenges: Bases for the assessment of smart city projects. Proceedings of 2015 International Conference on Smart Cities and Green ICT Systems (SMARTGREENS). Available at: https://ieeexplore.ieee.org/stamp/stamp.jsp?tp=\&arnumber $=7297938$

22. Bradford, N. (2004). Place matters and multi-level governance: Perspectives on a new urban policy paradigm. Policy Options, 25(2), 39-45.

23. Sylvie, D., Doran, M. A. (2013). GeoSmartCity: geomatics contribution to the Smart City [Text] / D. Sylvie, D., Doran M. A. Proceedings of 14th annual International Conference on digital Government research: From eGovernment to Smart Government, ACM, 65-71.

24. Li, Y. (2013). Analysis of the challenges and solutions of building a smart city. Proceedings of 2013 International Conference on Construction and Real Estate Management (ICCREM), ASCE, Reston, VA, 1511-1515.

25. Krinichansky, K.V. (2013). Sovremennuj rossijskiy gorod v svete tendentsij urbanisticheskogo mira [Contemporary Russian city in the light of the urbanistic world trends]. Regional Economics: Theory and Practice, 32 (311), 2-13.

26. Batty, M., Axhausen, K., Giannotti, F. [and other] (2012). Smart cities of the future. The European Physical Journal, 214, 482-518.

27. Fu, P. Weng, Q. (2016). A time series analysis of urbanization induced land use and land cover change and its impact on land surface temperature with Landsat imagery. Remote Sensing of Environment, 175, 4, $205-214$.

28. Batty, M. (2008). The size, scale, and shape of cities. Science, 319 (5864), 769-771.

29. Grimm, N.B. Fraeth, S.H., Golubiewski, N.E. [and other]. (2008). Global change and the ecology of cities. Science, 319(5864), 756-760.

30. Potere, D., Schneider, A. (2007). A critical look at representations of urban areas in global. GeoJournal, 69 (1), 55-80. 
31. Miyazaki, H., Shao, X., Iwao, K. [and other] (2013). An automated method for global urban area mapping by integrating ASTER satellite images and GIS data. IEEE Journal of Selected Topics in Applied Earth Observations and Remote Sensing, 6 (2), 1004-1019.

32. Wieland, M. Pittore, M. (2016). Large-area settlement pattern recognition from Landsat-8 data. ISPRS Journal of Photogrammetry and Remote Sensing, 119, 294-308.

33. Dong, P., Chen, Q. (2018). LiDAR Remote Sensing and Applications. Boca Raton: CRC Press, 246.

34. Giannotti, F., Nanni, M., Pedreschi, D. [and other]. (2011). Unveiling the complexity of human mobility by querying and mining massive trajectory data. The International Journal on Very Large Data Bases, 20(5), 695-719.

35. Song, C., Koren, T., Wang, P. [and other]. (2010). Modelling the scaling properties of human mobility. Nature Physics, 6, 818-823.

36. Song, C. Qu, Z., Blumm, N. [and other]. Limits of predictability in human mobility. Science, 327, $1018-1021$.

37. Felbier, A., Esch, T., Heldens, W. [and other]. (2014). The global urban footprint; processing status and cross comparison to existing human settlement products. IEEE Geoscience and Remote Sensing Symposium, 4816-4819.

38. Lazaroiu, G.C., Roscia, M. (2012). Definition methodology for the smart cities model. Energy, 47, $326-332$.

39. Desfor, G., Keil, R. (2004). Nature and the City: Making Environmnetal Policy in Toronto and Los Angeles. Tucson: the University of Arizona Press, 269.

40. Gil-García, J. R., Pardo, T. A. (2005). E-government success factors: Mapping practical tools to theoretical foundations, 22(2), 187-216.

41. Eger, J. M. (2009). Smart growth, smart cities, and the crisis at the pump a worldwide phenomenon. I-Ways, 32(1), 47-53.

42. Sagl, G. Blashker, T. (2015). Contextual sensing: integrating contextual information with human and technical geo-sensor information for Smart Cities, 15, 17013-17035.

43. Resch, B., Blaschke, T., Mittlboeck, M. (2010). Live geography: Interoperable geo-sensor webs facilitating the vision of digital earth. International Journal of Advanced Network Services, 3, 323-332.

44. Talari, S., Shafie-khah, M., Siano, P. (2017). A review of Smart Cities based on the Internet Of Things concept. Energies, 421(10), 3-26.

45. Merbitz, H., Buttstädt, M., Michael, S. (2012). Gis-based identification of spatial variables enhancing heat and poor air quality in urban areas. Applied Geography, 33, 94-106.

46. Sagl, G., Blaschke, T., Beinat, E. (2012). Ubiquitous geo-sensing for context-aware analysis: Exploring relationships between environmental and human dynamics, 12, 9835-9857.

47. Lukowicz, P., Choudhury, T., Gellersen, H. Beyond context awareness. IEEE Pervasive Computing, $10,15-17$.

48. Schmidt, A. Beigl, M., Gellersen, H.-W. (1999). There is more to context than location. Computer Graphics, 23, 893-901.

49. Naphade, M., Banavar, G., Harrison, C. [and other]. (2011). Smarter cities and their innovation challenges, 44 (6), 32-39.

50. Kostrikov, S., Kulakov, D., Sehida, K. (2014). Programne zabezpechennya GIS dlya LiDAR-technologii dustantsijjnogo zonduvannya $v$ tsilyah analizu urbogeosystem [GIS-software for the urban geosystem analysis with LiDAR-technique]. Proceedings of GIS Forum, 19, 45-52.

51. Filatov, V.M., Kostrikov, S.V. (2019). Towards the consideration of some aspects of the Smart City concept in the Human Geography perspective. REGION 2019: Human-Geographical aspects. Proceedings of the International Conference for young scientists and post-graduate students. Kharkiv, 108-111.

52. Kostrikov, S., Chuev, O. (2016). Analiz dvorivnevuh urbogeosystem cherez zasobu GIS [Analysis of the two-level urbogeosystems by GIS-tools]. Bulletin in Geology, Geography, and Ecology, 44, 98-109.

53. Bezruk, V., Kostrikov, S., Chuev, A. (2016). GIS-analiz funktsii urbogeosistemu z metoyu optimizatsii rozmishennya zakladiv gromadskogo harchuvanny (na prukladi $m$. Kharkiv [Optimizing allocation of catering institution establishment through the urbogeosystem GIS-analysis (case study of Kharkiv)]. Human Geography Journal, 21 (2), $91-$ 101.

54. Bourne, L.S., Simmons, J.W. (Editors). (1978). Systems of Cities: Readings on Structure, Growth, and Policy. Oxford: Oxford University Press, 565.

55. Torregrosa, A. Martin, M. (2014). Smart City concepts, Challengers and Projects. $1^{\text {st }}$ ASCIMER Workshop. EIBURS, 198-214.

56. Hancke, G.P., Silva, B., Hancke Jr, G. (2013). The role of advanced sensing in Smart Cities. Sensors, 13, $393-425$.

57. Lazaroiu, G.C., Roscia, M. (2012). Definition methodology for the smart city model, 47, 326-332.

58. Naphade, M. , Banavar, G., Harrison, G. (2011). Smarter cities and their innovation challenges, 44(6), 32-39.

59. Potere D., Schneider, A. Shlomol, A. [and other]. (2009). Mapping urban areas on a global scale: Which of the eight maps now available is more accurate. International Journal of Remote Sensing, 30 (24), 6531-6558.

60. Rathore, M.M., Ahmad, A. Paul, A. [and other]. (2016). Urban planning and building smart cities based on the Internet of Things using Big Data analytics. Computer Networks, 101, 63-80.

61. Allwinkle S., Cruickshank, P. (2011). Creating smart-er cities: An overview. Journal of Urban Technologies, 18, $1-16$. 
62. Kostrikov, S. Pudlo, R. Kostrikova, A. (2018). Three Key EOS LiDAR Tool Functionalities for Urban Studies. Full Paper Proceeding of ACRO'2018, Kuala Lumpur, Malaysia. Technical Session: LiDAR Data Processing, 3, 16761685.

63. Brenner, C. (2005). Building reconstruction from images and laser scanning. International Journal of Applied Earth Observation and Geoinformation, 6(3), 187-198.

64. Dorninger, P., Pfeifer, N. (2008). A comprehensive automated 3D approach for building extraction, reconstruction, and regularization from airborne laser scanning point clouds, 8(11), 7323-7343.

65. Haala, N., Kada, M. (2010). An update on automatic 3D building reconstruction // ISPRS Journal of Photogrammetry and Remote Sensing, 65(6), 570-580.

66. Musialski, P. Wonka, P., Aliaga, D.G. [and other]. (2013). A survey of urban reconstruction. Computer Graphics Forum, 32(6), 146-177.

67. Wang, R. (2013). 3D building modeling using images and LiDAR: a review. International Journal of Image and Data Fusion, 4(4), 273-292.

68. Ackermann, F. (1999). Airborne laser scanning - present status and future expectations. Journal of Photogrammetry \& Remote Sensing, 54(1), 64-67.

69. Sampath, A., Shan, J. (2010). Segmentation and reconstruction of polyhedral building roofs from aerial LIDAR point clouds. IEEE Transactions on Geoscience and Remote Sensing, 48(3), 1554-1567.

70. Vosselman, G., Dijkman, S. (2001). 3D building model reconstruction from point clouds and ground plans, 34 (3W4), 37-43.

71. Yan, W.Y., Shaker, A., El-Ashmawy, N. (2015). Urban land cover classification using airborne LiDAR data: A review. Remote Sensing of Environment, 158, 295-310.

72. Pu, S., Vosselman, G. (2009). Knowledge based reconstruction of building models from terrestrial laser scanning data. ISPRS Journal of Photogrammetry and Remote Sensing, 64, 575-584.

73. Orthuber, E. Avbelj, J. (2015). 3D building reconstruction from Lidar point clouds by adaptive dual contouring. ISPRS Annals of the Photogrammetry, Remote Sensing and Spatial Information Sciences, II-W4. Available at: https://pdfs.semanticscholar.org/d99b/d10b290a18a8070466a37f463c0886955f63.pdf

74. Biljecki, F. Stoter, J., Ledoux, H. [and other]. (2015). Applications of 3D City Models: State of the Art Review. ISPRS International Journal of Geo-Information, 4, 2842-2889.

75. Mezentsev, K., Oliynuk, Y., Mezentseva, N. (Editors). (2017). Urbanistuchna Ukraina; v epitsentre prostorovuh zmin [Urbanistic Ukraine: In the Epicentre of Spatial Alterations]. Collective monograph. Kyiv: Fenix, 438.

76. Akatov, N.B., Tolchin, S.V., Molyanov, P.V. [and other]. (2018). "Smart City" Project: premises of performability and successfulness. PNIPU Bulletin of social-economic sciences, 2, 116-126.

77. Kostrikov, S., Bubnov, D., Kostrikova, A. [and other]. (2018). ELiT web-application - the software for urban environment modeling and analysis. GIS Forum-2018. Kharkiv, 56-59.

78. Brail, R.K. (Editor). (2008). Planning Support Systems for Cities and Regions. Lincoln Institute of Land Policy, Cambridge, $M A, 312$.

79. Dwivedil, M. Uniyal, A., Mohan, R. (2015). New horizons in planning Smart Cities using LiDAR technology, 2(1), 40-50.

80. Hodgson, M.E. Uniyal, A., Mohan, R. [and other]. (2003). Synergistic use of LiDAR and color aerial photography for mapping urban parcel imperviousness. Photogrammetric Engineering and Remote Sensing, 69(90), 973-980.

81. Germaine, K.A., Hung, M.C. (2011). Delineation of impervious surface from multispectral imagery and LiDAR incorporating knowledge based expert system rules. Photogrammetric Engineering \& Remote Sensing, 77(1), 75-85.

82. Garcia-Gutierrez, J. L., Goncalves-Seco, L., Riquelme-Santos, J.S. (2011). Automatic environmental quality assessment for mixed-land zones using LiDAR and intelligent techniques. Expert Systems with Applications, 38(6), 6805-6813.

83. Stal, C., Tack, F., De Maeyer, P. [and other]. (2013). Airborne photogrammetry and LiDAR for DSM extraction and $3 D$ change detection over an urban area - a comparative study. International Journal of Remote Sensing, 34(4), 1087-1110.

84. Teo, T.-A., Shih, T.-Y. (2013). LiDAR-based change detection and change-type determination in urban areas. International Journal of Remote Sensing, 34(3), 968-981.

85. Khoshelham, K., Nardinocchi, C., Frontoni, E. [and other]. (2010). Performance evaluation of automated approaches to building detection in multisource aerial data. ISPRS Journal of Photogrammetry and Remote Sensing, $65,123-133$.

86. Dong, L., Shan, J. (2013). A comprehensive review of earthquake-induced building damage detection with remote sensing techniques. ISPRS Journal of Photogrammetry and Remote Sensing, 84, P. 85-99.

87. Baltsavias, E. P. (2004). Object extraction and revision by image analysis using existing geodata and knowledge: Current status and steps towards operational systems. ISPRS Journal of Photogrammetry and Remote Sensing, 58, $129-151$.

88. Vu, T.T., Yamazaki, F., Matsuoka, M. (2009). Multi-scale solution for building extraction from LiDAR and image data. International Journal of Applied Earth Observation and Geoinformation, 11, 281-289. 
89. Zhang, L., Xu, T., Zhang, J. (2012). Building extraction based on multiscale segmentation. 5th International Congress on Image and Signal Processing (CISP), October 16-18, 2012, 657-661.

90. Perron, J.T., Kirchner, J.W., Dietrich, W.E. (2009). Formation of evenly spaced ridges and valleys, 460, $502-505$.

91. Glenn, N.F., Streutker, D.R., Chadwick, D.J. [and other]. (2006). Analysis of LiDAR-derived topographic information for characterizing and differentiating landslide morphology and activity. Geomorphology, 73, 131-148.

92. Schulz, W.H. (2007). Landslide susceptibility revealed by LIDAR imagery and historical records, Seattle, Washington. Engineering Geology. 89, 67-87.

93. Dong P. (2012). A framework for automated assessment of post-earthquake building damage using geospatial data. International Journal of Remote Sensing, 33, 81-100.

94. Zhu, Q., Hu, M., Zhang, Y. (2009). Research and practice in three-dimensional city modeling. Geo-Spatial Information Science, 12, 18-24.

95. Giannotti, F., Pedreschi, D. (2008). Mobility, Data Mining and Privacy: Geographic Knowledge Discovery. Springer, Berlin, 412.

96. Zhang, X., Du, S. (2015). A linear dirichlet mixture model for decomposing scenes: Application to analyzing urban functional zonings. Remote Sensing of Environment, 169, 37-49.

97. Wen, D., Huang, X., Zhang, L. (2016). A novel automatic change detection method for urban high resolution remotely sensed imagery based on multiindex scene representation. IEEE Transactions on Geoscience and Remote Sensing, 54(1), 609-625.

98. Kabolizade, M., Ebadi, H., Ahmadi, S. (2010). An improved snake model for automatic extraction of buildings from urban aerial images and LiDAR data. Computers, Environment and Urban System, 34, 435-441.

99. Susaki, J. (2013). Knowledge-based modeling of buildings in dense urban areas by combining airborne LiDAR data and aerial images, 5, 5944-5963.

100. Ng, E. (2009). Policies and technical guidelines for urban planning of high-density cities - air ventilation assessment (AVA) of Hong Kong. Building and Environment, 44(7), 1478-1488. 